\title{
The role of GDNF family ligand signalling in the differentiation of sympathetic and dorsal root ganglion neurons
}

\author{
Uwe Ernsberger
}

Received: 4 February 2008 / Accepted: 5 May 2008 / Published online: 16 July 2008

(C) The Author(s) 2008

\begin{abstract}
The diversity of neurons in sympathetic ganglia and dorsal root ganglia (DRG) provides intriguing systems for the analysis of neuronal differentiation. Cell surface receptors for the GDNF family ligands (GFLs) glial cellline-derived neurotrophic factor (GDNF), neurturin and artemin, are expressed in subpopulations of these neurons prompting the question regarding their involvement in neuronal subtype specification. Mutational analysis in mice has demonstrated the requirement for GFL signalling during embryonic development of cholinergic sympathetic neurons as shown by the loss of expression from the cholinergic gene locus in ganglia from mice deficient for ret, the signal transducing subunit of the GFL receptor complex. Analysis in mutant animals and transgenic mice overexpressing GFLs demonstrates an effect on sensitivity to thermal and mechanical stimuli in DRG neurons correlating at least partially with the altered expression of transient receptor potential ion channels and acid-sensitive cation channels. Persistence of targeted cells in mutant ganglia suggests that the alterations are caused by differentiation effects and not by cell loss. Because of the massive effect of GFLs on
\end{abstract}

U.E. is supported by the Deutsche Forschungsgemeinschaft (Er145-4) and by the Gemeinnützige Hertie-Stiftung.

\section{U. Ernsberger $(\bowtie)$}

Interdisciplinary Center for Neurosciences (IZN),

University of Heidelberg,

INF 307 ,

69120 Heidelberg, Germany

e-mail: uwe.ernsberger@urz.uni-heidelberg.de

U. Ernsberger

Max-Planck-Institute for Brain Research,

Deutschordenstrasse 46,

60528 Frankfurt, Germany neurite outgrowth, it remains to be determined whether GFL signalling acts directly on neuronal specification or indirectly via altered target innervation and access to other growth factors. The data show that GFL signalling is required for the specification of subpopulations of sensory and autonomic neurons. In order to comprehend this process fully, the role of individual GFLs, the transduction of the GFL signals, and the interplay of GFL signalling with other regulatory pathways need to be deciphered.

Keywords GFRalpha $\cdot$ GDNF Ret .

Sympathetic ganglion · Dorsal root ganglion .

TRP family channel $\cdot$ Development

$\begin{array}{ll}\text { Abbreviations } \\ \text { ASIC } & \text { acid-sensitive ion channel } \\ \text { Bax } & \text { bcl-2 associated pro-apoptotic protein } \\ \text { ChAT } & \text { choline acetyltransferase } \\ \text { CGRP } & \text { calcitonin gene-related peptide } \\ \text { DBH } & \text { dopamine beta-hydroxylase } \\ \text { DRG } & \text { dorsal root ganglion } \\ \text { E } & \text { embryonic day } \\ \text { EGFP } & \text { enhanced green fluorescent protein } \\ \text { GDNF } & \text { glial cell-line-derived neurotrophic factor } \\ \text { GFL } & \text { GDNF family ligand } \\ \text { GFP } & \text { green fluorescent protein } \\ \text { GFRalpha } & \text { GFL receptor alpha subunit } \\ \text { HTMR } & \text { high-threshold mechanoreceptor } \\ \text { IB4 } & \text { Griffonia simplicifolia isolectin B4 } \\ \text { IHC } & \text { immunohistochemistry } \\ \text { IR } & \text { immunoreactivity } \\ \text { ISH } & \text { in situ hybridization } \\ \text { LTMR } & \text { low-threshold mechanoreceptor } \\ \text { NGF } & \text { nerve growth factor } \\ \text { P } & \text { postnatal day }\end{array}$


PCNA proliferating nuclear cell antigen

PGP9.5 neuron-specific protein gene product 9.5

ret "rearranged during transfection" protooncogene

RT-PCR polymerase chain reaction on template synthesized by reverse transcription

SCG superior cervical ganglion

SP substance P

STG stellate ganglion

TGM tau-EGFP-myc

$\mathrm{TH} \quad$ tyrosine hydroxylase

TTX tetrodotoxin

trk tyrosine kinase receptor, high-affinity neurotrophin receptor

TRP transient receptor potential family of cation channels

VAChT vesicular acetylcholine transporter

VIP vasoactive intestinal peptide

\section{Introduction}

The differentiation of the diverse classes of neurons from their precursor cells is orchestrated by a range of intrinsic and extrinsic regulators that are becoming increasingly well characterized. Candidate extrinsic effectors encompass a multitude of peptide growth factors with nerve growth factor (NGF) as the prototypic neurotrophic factor. The related factors of the neurotrophin family and their high-affinity cell surface receptors trkA (tyrosine kinase receptor, high-affinity neurotrophin receptor A), trkB and trkC (Fig. 1) were characterized starting in the 1980s; this work has demonstrated in particular their survival-promoting activity (for a review, see Snider 1994). In the 1990s, GDNF family ligands (GFLs) were found by using similar neuron survival assays. Cloning of the genes coding for glial cell-line-derived neurotrophic factor (GDNF), neurturin, artemin and persephin and their cell surface receptors GFRalpha1 to GFRalpha4 acting in a complex with the receptor tyrosine kinase ret ("rearranged during transfection" proto-oncogene; for a review, see Airaksinen and Saarma 2002; Fig. 1) has allowed the analysis of their in vivo function in mutant mice. Surprisingly, mutant analysis in the peripheral sensory and sympathetic nervous system shows that GFL signalling does not play a prominent role in supporting neuronal survival. Instead, neurite outgrowth and differentiation are major targets of these signalling pathways. Here, I will review the data available regarding the role of GFLs in the development of neurons in sympathetic ganglia and dorsal root ganglia (DRG), two of the most studied model populations for neuronal differentiation.

The neurons of sympathetic ganglia and DRG are both derived from the neural crest (LeDouarin and Kalcheim
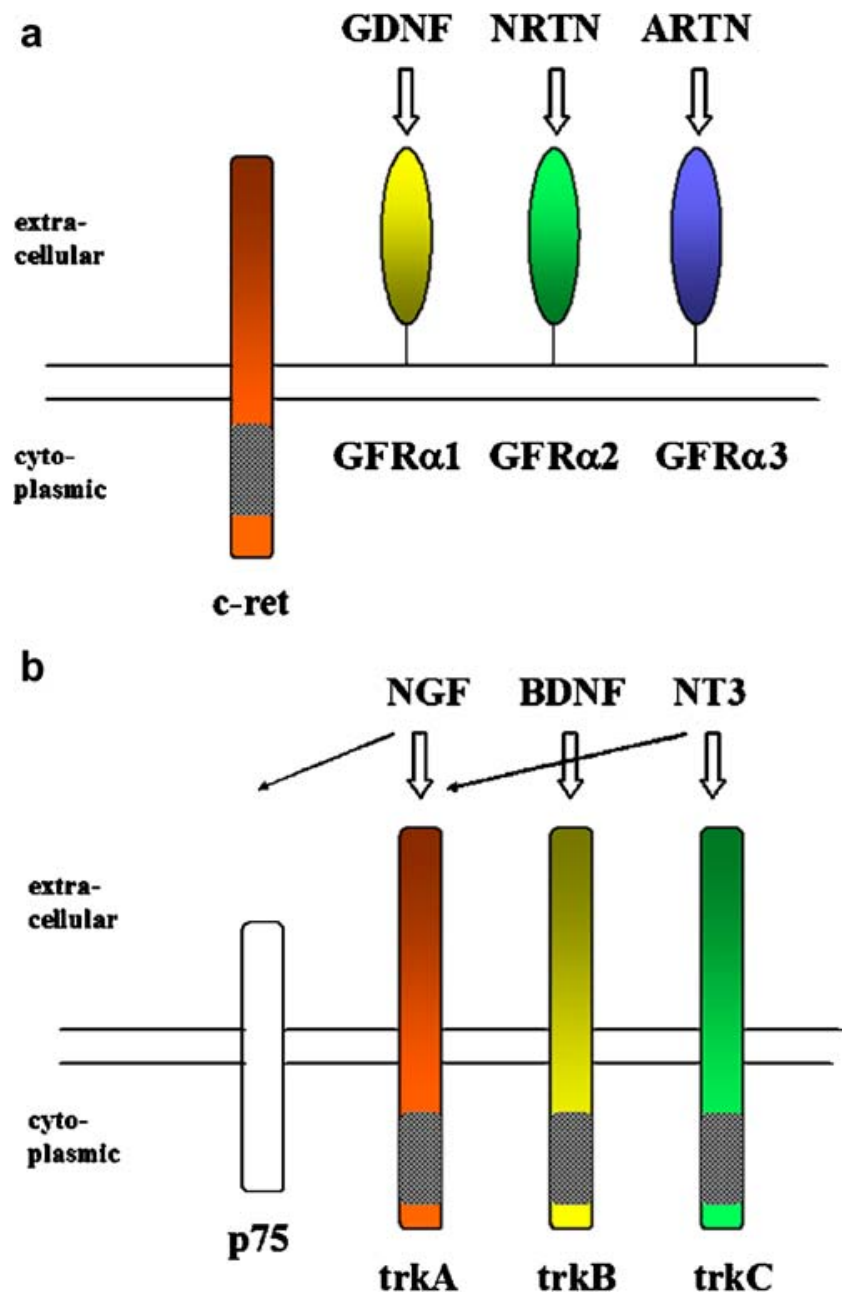

Fig. 1 Cell surface receptors for GDNF family ligands and neurotrophins in the peripheral nervous system. a The GDNF family ligands, viz. glial cell-line-derived neurotrophic factor $(G D N F)$, neurturin (NRTN) and artemin (ARTN), bind to the alpha receptor subunits GFRalpha1, GFRalpha2 and GFRalpha3, respectively. GFRalphas are linked to the membrane via glycosyl phosphatidylinositol anchors. Signal transduction occurs by interaction with the transmembrane receptor ret $(c-r e t)$. The intracellular tyrosine kinase domain of ret is indicated by grey shading. GFRalpha4, which binds persephin, is not found in sympathetic ganglia and dorsal root ganglia (DRG). Modified from Airaksinen and Saarma (2002). b The neurotrophins, viz. nerve growth factor $(N G F)$, brain-derived neurotrophic factor $(B D N F)$ and neurotrophin 3 (NT3) bind with high affinity to the tyrosine kinase receptors trkA, trkB and trkC, respectively. NT3 may also act via trkA. p75 is a low affinity neurotrophin receptor

1999). In an early segregation event, the autonomic and sensory lineages diverge. Within these lineages, a subsequent diversification process that lasts from the time of ganglion formation well into postnatal development leads to the generation of an array of specialized neurons suited to subserve distinct functions.

Diversity of neuronal properties is apparent in the physiological and neurochemical domain. Sympathetic neurons innervating distinct target tissues such as blood vessels or 
sweat glands differ in activity patterns, preganglionic connectivity and neurotransmitter phenotype (for reviews, see Jänig and McLachlan 1992; Ernsberger 2001). DRG neurons conducting different qualities of afferent information differ in receptive properties, ion channel equipment, central and peripheral projection patterns and neuropeptide phenotype (for reviews, see Burgess and Perl 1973; Brown 1981; Schultzberg 1983).

Because of the availability of histochemical methods to detect catecholamines including noradrenaline, the main transmitter of sympathetic neurons, the development of sympathetic neurotransmitter properties became an early focus of research into neuronal development. With the establishment of reliable methods to analyse the expression of mRNA and protein for transmitter-synthesizing enzymes, the development of noradrenergic and of cholinergic properties in sympathetic neurons could be studied at the level of gene expression (for reviews, see Ernsberger and Rohrer 1996, 1999; Ernsberger 2000, 2001). Of particular interest as markers for the noradrenergic and cholinergic transmitter phenotype are the enzymes of noradrenaline biosynhesis, tyrosine hydroxylase $(\mathrm{TH})$ and dopamine $\beta$-hydroxylase (DBH), and the enzyme synthesizing acetylcholine, choline acetyltransferase (ChAT), which is coexpressed from the cholinergic gene locus with the vesicular acetylcholine transporter (VAChT). The lack of ChAT and VAChT expression in sympathetic ganglia of mice mutant for ret, the signal transducing subunit of the GFL receptor complex, demonstrates the role of GFL signalling in cholinergic development (Burau et al. 2004).

For afferent neurons in the DRG, the marked specificity in response to diverse mechanical, thermal and chemical stimuli detected in electrophysiological single-unit recordings provokes the question regarding the molecular apparatus underlying this specific transduction process and the developmental regulation of its assembly. With the recent characterization of proteins involved in the transduction process of mechanical, thermal and chemical stimuli, such as proteins from the transient receptor potential (TRP) channel family (for reviews, see Jordt et al. 2003; Koltzenburg 2004; Lumpkin and Caterina 2007), and the analysis of their expression during DRG neuron development (Hjerling-Leffler et al. 2007; Elg et al. 2007), molecular analysis of DRG neuron specification comes within reach. The effect of ret gene mutation on TRP channel expression (Luo et al. 2007) demonstrates the importance of GFLs for sensory neuron specification.

Here I discuss studies of transgenic GFL overexpression and studies from mouse mutants. The mutant analysis compares knockout mice for the GFLs GDNF, neurturin and artemin, their preferred alpha receptor subunits GFRalpha1, GFRalpha2 and GFRalpha3, respectively, and the common signal transducing subunit ret (Airaksinen and Saarma 2002).

\section{Developmental expression of genes specifying neuronal diversity}

ret and GFRalpha subunits

ret and GFRalpha expression patterns

in sympathetic ganglia

The expression of mRNAs for GFRalpha1, GFRalpha2, GFRalpha3 and ret is dynamically regulated in mouse sympathetic ganglia during embryogenesis (Nishino et al. 1999; Enomoto et al. 2001). Expression of a tau-EGFP (enhanced green fluorescent protein)-myc (TGM) reporter from the ret locus indicates that at embryonic day 11.5 (E11.5) all precursors in the superior cervical ganglion (SCG) and stellate ganglion (STG) express ret (Enomoto et al. 2001). Most cells lose ret expression by E15.5 and only a subpopulation of sympathetic cells expresses ret at postnatal day $0(\mathrm{P} 0)$. The downregulation shown with the reporter construct is confirmed by ret immunohistochemistry (IHC; Enomoto et al. 2001). In situ hybridization (ISH) shows widespread expression in sympathetic ganglia at E13 and expression in neuron subpopulations at various labelling intensities at P0 (Fig. 2).

GFRalphal mRNA as analysed by ISH is detectable at E12.5, gradually decreases thereafter and is undetectable at P5 (Nishino et al. 1999). mRNAs for GFRalpha2 and GFRalpha3 are expressed in most SCG cells at E12.5 and subsequently become restricted to smaller subpopulations. At P5, 20\%$30 \%$ of SCG cells express GFRalpha3. At P60, GFRalpha3 expression is undetectable by ISH (Nishino et al. 1999). GFRalpha2 yields strong signals by ISH at P0, whereas GFRalpha3 gives moderate signals (Fig. 3).

\section{ret and GFRalpha expression in DRG}

ret-positive cells develop largely but not exclusively from trkA-positive cells In adult rats, 59\%-64\% of lumbar DRG neurons express ret mRNA as detected by ISH (Bennett et al. 1998, 2000; Kashiba et al. 1998, 2003) and 72\% are found positive for ret protein by IHC (Bennett et al. 1998). In mice, percentages of cells expressing ret mRNA as determined by ISH range from $40 \%$ (Zwick et al. 2002) to $60 \%$, corresponding to $62 \%$ immunopositive cells (Molliver et al. 1997).

During mouse development, a small subpopulation of retpositive cells is detectable at E11.5. The early ret-positive cells do not express trkC (Kramer et al. 2006) or trkA (Luo et al. 2007), as analysed by double IHC and double ISH, respectively. At E12, however, $80 \%$ of the ret-immunoreactive neurons express trkB (Kramer et al. 2006). By E14.5, only a few ret-positive cells coexpress any trk receptor.

At E15, $\sim 10 \%$ of lumbar DRG neurons express ret (Molliver et al. 1997) and, at E16, 24\% (Baudet et al. 2000). Whereas the early trkA-negative ret-positive cells have a large 

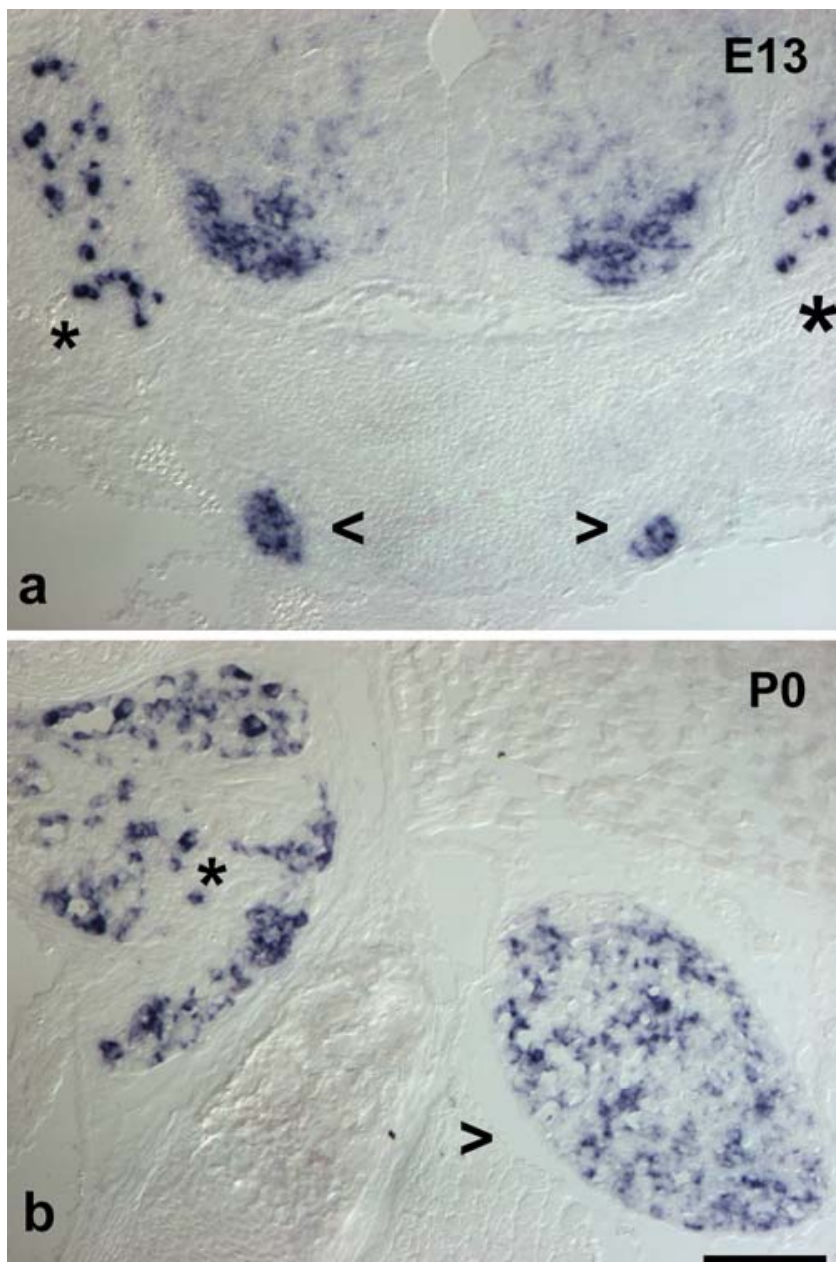

Fig. 2 Expression of ret mRNA in sympathetic ganglia and DRG. In situ hybridization for ret mRNA on trunk cross sections from a 13day-old mouse embryo $(E 13, \mathbf{a})$ and a newborn animal $(P 0, \mathbf{b})$. At E13, a population of large DRG (asterisks) neurons is positive, whereas many DRG cells are devoid of signal. Staining is found throughout the sympathetic ganglia (open arrowheads) albeit at various intensities. In newborn DRG, a small population of large neurons is strongly positive, whereas many small cells show weak signal. In sympathetic ganglia, a subset of cells is ret-positive at varying signal intensities. Bar $70 \mu \mathrm{m}$

diameter, small trkA-positive and ret-positive neurons appear at later stages. Many trkA-positive neurons coexpress ret at E16 and these are small to medium in size (Luo et al. 2007). In newborn animals, ret expression has been detected in $45 \%$ of neurons (Molliver et al. 1997; Baudet et al. 2000; compare Fig. 2) and, at P7.5, the adult pattern is established, with ret being expressed in small- and large-diameter neurons.

Fig. 3 Expression of mRNAs for GFRalpha2 and GFRalpha3 in sympathetic ganglia and DRG of a newborn mouse. In situ hybridization for GFRalpha2 mRNA $(G F R \alpha 2$, a) and GFRalpha3 mRNA $(G F R \alpha 3$, b) shows strong GFRalpha2 expression in the majority of neurons in a sympathetic ganglion (open arrowhead) and a DRG (asterisk). Strong GFRalpha3 expression is detectable in a population of DRG neurons. Weak GFRalpha3 labelling is found in some DRG and many sympathetic ganglion neurons. Bar $70 \mu \mathrm{m}$
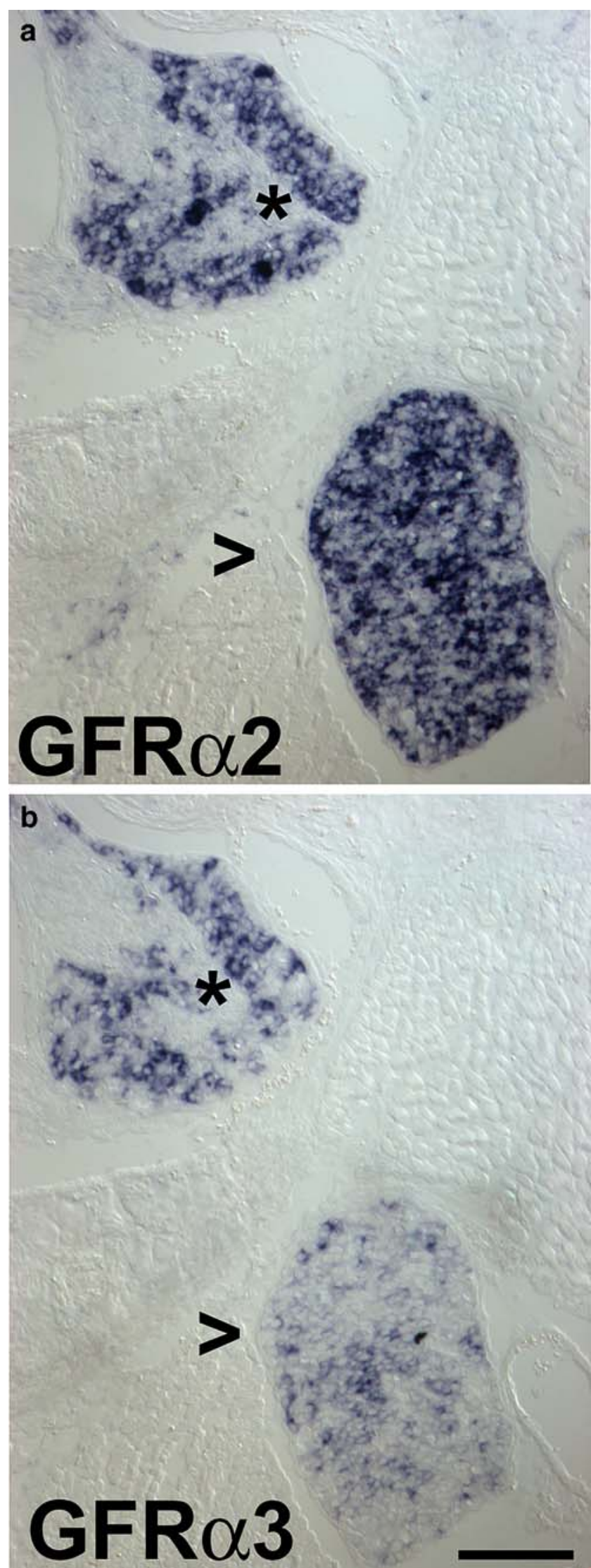
Many but not all ret-positive cells lose trkA expression postnataly and bind the lectin, Griffonia simplicifolia isolectin B4 Postnatally, neurons coexpressing ret and trkA, as analysed by double ISH, undergo trkA extinction, which appears to be complete at P14 (Luo et al. 2007). This process is ret-dependent as it is slowed down in ret mutants. Conversely, ret expression is NGF-dependent as, in NGF/Bax (bcl-2 associated pro-apoptotic protein) double-mutants, only a few ret-positive neurons are present at $\mathrm{P} 0$ and these are trkA-negative (Luo et al. 2007).

In mature animals, the overlap of ret and trkA expression is limited and amounts to $\sim 5 \%-15 \%$ in mouse lumbar segment 5 (L5) DRG (Molliver et al. 1997; Orozco et al. 2001). In adult rat, $26 \%-28 \%$ of trkA-positive cells in lumbar DRG express ret and $15 \%$ of ret-positive cells express trkA (Bennett et al. 1998; Kashiba et al. 1998, 2003). A total of $9 \%$ of DRG neurons express both. Approximately half of trkB- and trkCpositive cells express ret (Kashiba et al. 2003). About 30\% of ret-immunoreactive cells are calcitonin gene-related peptide (CGRP)-positive (Bennett et al. 1998).

Massive overlap is found between ret expression and binding of the lectin Griffonia simplicifolia isolectin B4 (IB4). In lumbar DRG of adult rat and mouse, 95\% and $100 \%$, respectively, of IB4-binding cells are ret-positive (Bennett et al. 1998; Molliver et al. 1997) and $~ 80 \%$ and $\sim 70 \%$ of ret-positive cells bind IB4, respectively (Bennett et al. 1998; Kashiba et al. 2001; Molliver et al. 1997). IB4binding neurons constitute a population of functionally distinct nociceptors that differ in the duration of action potentials (Stucky and Lewin 1999; Fang et al. 2006), amplitude of heatactivated currents, density of tetrodotoxin (TTX)-resistent sodium currents (Stucky and Lewin 1999) and immunoreactivity (IR) for the sodium channel Nav1.9 (Fang et al. 2006). Because of the limited colocalization of IB4 binding and CGRP expression (Silverman and Kruger 1990), peptidergic and nonpeptidergic nociceptors have been distinguished and are correlated with trkA and ret expression, respectively. However, of note, not all IB4-binding cells are nociceptors (Fang met al. 2006), some trkA-positive cells bind IB4 and some retpositive cells show no IB4 binding (Kashiba et al. 2001).

There is a large but incomplete overlap of ret and GFRalpha expression ret expression overlaps largely with expression of
GFRalpha1, GFRalpha2 and GFRalpha3. Of ret-positive lumbar DRG neurons, 66\% express GFRalpha1 in adult rat (Kashiba et al. 2003) and 89\% in adult mice (Molliver et al. 1997), as analysed by ISH on serial sections and double ISH, respectively. In $\mathrm{P} 14$ mice, $18 \%$ of ret-positive cells express GFRalpha1 as analysed by double ISH (Luo et al. 2007). Some $34 \%$ of ret-positive cells express GFRalpha 2 and $33 \%$ express GFRalpha3 in the lumbar DRG of adult rat (Kashiba et al. 2003). In P14 mice, 61\% and 14\% of ret-positive cells express GFRalpha2 and GFRalpha3, respectively (Luo et al. 2007). Conversely, 79\% of GFRalpha1-positive cells express ret (Kashiba et al. 2003) and more than $90 \%$ of GFRalpha2and GFRalpha3-expressing cells are ret-positive in adult rats (Kashiba et al. 1998, 2003; Orozco et al. 2001). In adult mice, $82 \%$ of GFRalpha3-positive cells express ret, as analysed by double IHC (Orozco et al. 2001). Data on the coexpression of GFRalpha receptors differ between studies (Bennett et al. 1998; Kashiba et al. 2003).

Expression of GFRalpha1 and GFRalpha2, but not GFRalpha3, depends on NGF, as shown in newborn NGF/ Bax double-mutant mice where GFRalphal is undetectable and GFRalpha2 expression is strongly reduced (Luo et al. 2007). Polymerase chain reaction on template synthesized by reverse transcription (RT-PCR) in sensory neuron cultures indicates that this may be a direct effect of NGF on neuronal mRNA levels. In addition, GFRalpha1- and GFRalpha2expressing cells are reduced at $\mathrm{P} 2$ and $\mathrm{P} 10$ in ret mutants by $60 \%$ and $25 \%$, respectively (Luo et al. 2007).

The results suggest that NGF signalling controls the initial expression of GFRalpha1 and GFRalpha2, whereas ret autoregulates their levels at later stages. Signals regulating GFRalpha3 expression remain to be determined.

GFRalphas are expressed in relatively large DRG neuron subpopulations Overall, the proportion of GFRalpha1-positive cells among DRG neurons is $40 \%-50 \%$ at lumbar levels in adult rats (Bennett et al. 1998, 2000; Kashiba et al. 1998, 2003 ) and $20 \%$ at thoracic levels in adult humans (Josephson et al. 2001), as analysed by ISH (Table 1). GFRalpha2positive neurons constitute $19 \%-33 \%$ of lumbar DRG neurons in adult rats (Bennett et al. 1998, 2000; Kashiba et al. 2003) and $51 \%$ of thoracic DRG neurons in adult humans (Josephson et al. 2001). GFRalpha3-positive cells make up

Table 1 GFRalpha expression in mammalian DRG. All studies were performed by in situ hybidization ( $F G$ fluoro-gold, $L$ lumbar, $T$ thoracic)

\begin{tabular}{|c|c|c|c|c|c|c|}
\hline Species & Stage & Level & GFRa1 & GFRa2 & GFRa3 & Reference \\
\hline Mouse & Neonatal & Lumbar & 17 & 22 & 34 & Baudet et al. 2000 \\
\hline \multirow[t]{4}{*}{ Rat } & Adult & Lumbar & 41 & 33 & - & Bennett et al 1998 \\
\hline & & $\mathrm{L} 4 / 5$ & 42 & 32 & 42 & Bennett et al. 2000 \\
\hline & & \multicolumn{5}{|c|}{ Retrograde FG labelling from sciatic nerve } \\
\hline & & $\mathrm{L} 4 / 5$ & 50 & 19 & 17 & Kashiba et al. 2003 \\
\hline Human & Adult & $\mathrm{T} 11 / 12$ & 20 & 51 & 32 & Josephson et al. 2001 \\
\hline
\end{tabular}


$20 \%$ of lumbar mouse DRG (Orozco et al. 2001) and 17\%$42 \%$ in adult rat (Bennett et al. 2000; Orozco et al. 2001; Kashiba et al. 2003) and 32\% in adult humans (Josephson et al. 2001) at lumbar and thoracic levels, respectively.

During mouse development mRNAs for GFRalphal and GFRalpha 2 have been detected by ISH at low levels at E13 and E16 and expression is strongly increased at birth (Baudet et al. 2000) and for GFRalpha2 after birth (Luo et al. 2007). In neonatal mice, $17 \%$ and $22 \%$ of lumbar DRG neurons are positive for GFRalpha1 and GFRalpha2, respectively (Baudet et al. 2000). GFRalpha3 mRNA is expressed at low levels at E13 in most neurons and at high levels at E16 in the majority of neurons. At birth, high expression levels are found in $34 \%$ of lumbar DRG neurons.

Whereas GFRalpha1-positive cells belong to all size groups (Bennett et al. 1998; Baudet et al. 2000), the majority of GFRalpha2- and GFRalpha3-positive cells are of a small size (Bennett et al. 1998; Baudet et al. 2000; Orozco et al. 2001; Lindfors et al. 2006). In the GFRalpha3-positive neuron population, $80 \%$ and $88 \%$ are trkA-positive, $70 \%$ and $97 \%$ are CGRP-positive and $94 \%-99 \%$ and $97 \%$ are TRPV1-positive in mouse and rat, respectively (Orozco et al. 2001; Malin et al. 2006). This population does not contain large-diameter neurons in mice (Baudet et al. 2000). In contrast, only $1.5 \%$ of GFRalpha2-positive neurons in mice coexpress CGRP (Lindfors et al. 2006) and less than $20 \%$ of GFRalpha2-expressing cells are TRPV1-positive (Malin et al. 2006; Lindfors et al. 2006). This population contains preferentially small neurons positive for peripherin, a marker for unmyelinated neurons as analysed in mice (Lindfors et al. 2006). Moreover, in rat, the vast majority (87\%) of DRG neurons that bind and transport the GFRalpha2 ligand neurturin are of a small size (Leitner et al. 1999). Only 3\% of the neurturin-labelled cells express trkA.

Thus, GFRalpha3-positive neurons constitute a peptidergic nociceptor population, which to a large extent coexpresses trkA and ret. The large majority of GFRalpha2-positive neurons are small non-peptidergic cells that lack trkA.

Transmitter phenotype in sympathetic ganglia

Mature sympathetic ganglia in birds and mammals contain two populations of neurons that differ in their neurotransmitter phenotype. The majority of neurons synthesizes and releases noradrenaline, whereas a small subpopulation uses acetylcholine (for a review, see Ernsberger and Rohrer 1999). The two neuron populations differ in their expression of transmittersynthesizing enzymes and the vesicular transporters required for loading transmitter or transmitter precursor into synaptic vesicles. For both transmitter phenotypes, genes coding for the characteristic proteins appear to be regulated as synexpression groups (for a review, see Ernsberger 2004). mRNAs for $\mathrm{TH}$ and $\mathrm{DBH}$, the rate-limiting and the final enzyme of noradrenaline biosynthesis, respectively, are induced in parallel at an early stage (E3) during the formation of primary sympathetic ganglia in chick (Ernsberger et al. 2000). In the mouse embryo, TH is detected at E9 (Pattyn et al. 1999). mRNAs for the enzyme of acetylcholine biosynthesis, ChAT, and the transporter VAChT are detectable later, at E7 in the chick embryo (Ernsberger et al. 1997) and E10 in the mouse embryo (Huber and Ernsberger 2006). Initially, the expression of both sets of genes occurs throughout the sympathetic ganglia in both species and coexpression has been shown in E7 chick ganglia by IHC and ISH (Ernsberger et al. 1997). Later, expression of noradrenergic and cholinergic features segregates to distinct neuron populations (Ernsberger et al. 1997; Burau et al. 2004). An essential aspect of this process is the loss of ChAT and VAChT expression in a large number of sympathetic neurons (Burau et al. 2004). At E18 in chick, when the segregation of noradrenergic and cholinergic properties to different sympathetic neuron populations shows in largely non-overlapping patterns of mRNA distribution apparent after ISH (Ernsberger et al. 1997), trkA expression almost perfectly colocalizes with the expression of the noradrenaline transporter and negatively correlates with ChAT (Brodski et al. 2002). Instead, ChAT expression colocalizes with trkC. In addition, ret mRNA colocalizes in double ISH with mRNA for the neuropeptide vasoactive intestinal peptide (VIP), which in sympathetic ganglia is coexpressed with cholinergic properties (Ernsberger et al. 2000).

\section{TRP channel expression}

Cloning of the capsaicin receptor (VR1/TRPV1) and demonstration of its heat sensitivity (Caterina et al. 1997; Tominaga et al. 1998) has provided a remarkably simple explanation of aspects of the puzzlingly diverse response spectrum of polymodal nociceptors. Mutational inactivation of TRPV1 demonstrates its involvement in the detection of noxious chemical and thermal stimuli by DRG neurons and in the development of thermal hyperalgesia in an inflammatory setting (Caterina et al. 2000; Davis et al. 2000; but see Woodbury et al. 2004). Other members of the family also respond to elevated temperatures, with TRPV2 being activated at a remarkably high heat threshold (for a review, see Jordt et al. 2003). In addition to TRPV1 and V2 as heat sensors, TRPA1 (Kwan et al. 2006; but see Bautista et al. 2006) and TRPM8 (Bautista et al. 2007; Colburn et al. 2007; Dhaka et al. 2007) have been reported as cold sensors.

TRPV1, TRPM8 and TRPA1 are expressed preferentially in small neurons of mature rat DRG (Kobayashi et al. 2005). Of lumbar DRG neurons, 47\% express TRPV1 mRNA or IR in adult rat (Michael and Priestley 1999; Orozco et al. 2001; Kobayashi et al. 2005) and 22\%-38\% show TRPV1 IR in adult mice (Orozco et al. 2001; Zwick et al. 2002). In adult 
rat DRG, $23 \%$ and $40 \%$ of the neurons express TRPM8 and TRPA1 mRNA, respectively (Kobayashi et al. 2005). The TRPV1-expressing population includes the TRPA1-positive cells (Kobayashi et al. 2005) but overlap with TRPM8 is restricted. Of TRPM8 mRNA-positive cells, 30\% are TRPV1-immunoreactive in rat (Okazawa et al. 2004) and no overlap is found in mice (Peier et al. 2002; Dhaka et al. 2008). TRPM8-positive cells in mice have been shown by EGFP expression from the TRPM8 locus to mark a unique population of DRG neurons, the majority of which does not coexpress nociceptive markers (Dhaka et al. 2008).

In adult rat, $\sim 60 \%$ of the TRPV1-immunoreactive cells in L5 DRG show ret IR (Guo et al. 2001). In adult rat and mouse, $97 \%$ and $99 \%$ of GFRalpha3-immunoreactive L5 DRG neurons are TRPV1-immunoreactive, respectively, but $\sim 50 \%$ of the TRPV1-immunoreactive neurons are not GFRalpha3-positive (Orozco et al. 2001). TRPV1 expression and IB4 binding overlap to different degrees in rodents. In adult rat, $50 \%-75 \%$ of IB4-binding neurons express TRPV1 (Michael and Priestley 1999; Guo et al. 2001; Price and Flores 2007) and 70\%-80\% of TRPV1-immunoreactive cells bind IB4 (Guo et al. 2001; Price and Flores 2007). In mice, only $2 \%-6 \%$ of IB4-binding neurons in $\mathrm{L} 4 / 5 \mathrm{DRG}$ express TRPV1 IR (Zwick et al. 2002; Woodbury et al. 2004; Breeze et al. 2005). No IB4-binding is observed in TRPM8-expressing DRG neurons in mouse (Peier et al. 2002; Dhaka et al. 2008).

TRPV1, TRPM8 and TRPA1 are coexpressed with trkA, whereas overlap with the trkB- and trkC-positive population is minor $(<4 \%)$ in adult rat (Kobayashi et al. 2005). TRPV1 and TRPA1 expression overlaps partially with trkA in adult rat DRG. Approximately $45 \%$ of the TRPV1- and TRPA1positive cells express trkA, whereas 51\%-65\% (Kobayashi et al. 2005; Michael and Priestley 1999) and 36\% (Kobayashi et al. 2005) of the trkA-positive cells express TRPV1 and TRPA1, respectively. Double ISH has shown the expression of trkA in virtually all TRPM8-positive cells (98\%), with almost half $(43 \%)$ of trkA-positive neurons expressing TRPM8.

During mouse development, TRPV1-immunoreactive cells are first detected at E13.5 in DRG neurons (Tamura et al. 2005). Capsaicin responses are rarely observed in acutely dissociated DRG cells from E11.5 DRG with a strong increase in the proportion of responsive cells between E12.5 (5\%) and E14.5 (64\%) and a postnatal decline to $40 \%$ (Hjerling-Leffler et al. 2007). TRPM8 is first detected at E16.5 by ISH (Chen et al. 2006). IR is not detected at E15.5 but in few cells at E17.5 (Tamura et al. 2005). This coincides nicely with the onset of menthol responsiveness in cultures taken from E16.5 mouse embryos (Hjerling-Leffler et al. 2007).

During rat postnatal development, the proportion of TRPV1-immunoreactive cells coexpressing ret increases from $30 \%$ at $\mathrm{P} 2$ to $\sim 50 \%$ at $\mathrm{P} 10$ and $\sim 60 \%$ at $\mathrm{P} 40$ (Guo et al. 2001).
The proportion of TRPV1-immunoreactive cells that coexpresses trkA declines from $\sim 60 \%$ at $\mathrm{P} 2$ to $\sim 50 \%$ at $\mathrm{P} 10$ and $\sim 30 \%$ at $\mathrm{P} 40$. During the same time period, coexpression of TRPV1 and substance P (SP) appears unaltered. TRPV1-immunoreactive cells constitute $\sim 70 \%-80 \%$ of the SP-immunoreactive population and $30-35 \%$ of the TRPV1positive cells express SP (Guo et al. 2001). The proportion of CGRP-immunoreactive cells in mice coexpressing TRPV1, however, is reported to triple from $20 \%$ to $60 \%$ of CGRP-positive cells between P1 and P7 when the percentage of TRPV1-immunoreactive cells expressing CGRP increases from $40 \%$ to $60 \%$ (Funakoshi et al. 2006). Both numbers remain stable until P56.

The datasets show that $50 \%-60 \%$ of ret-expressing and trkA-positive neurons express the heat detector TRPV1. In the trkA-positive population, TRPM8 expression appears to segregate to the TRPV1-negative population. In addition, the observations suggest that the decline in coexpression with trkA does not coincide with a decline in neuropeptide coexpression.

Different developmental expression patterns of population-specific properties

Expression of the genes coding for the proteins discussed in this review begins at embryonic stages in neurons from sympathetic ganglia and DRG (Table 2). The pattern of expression may appear restricted to defined subpopulations from the onset, as shown for ret in DRG neurons (Figs. 2, 4) or widespread as observed for ret and cholinergic properties in sympathetic neurons (Fig. 5). An increase in the proportion of ret-positive cells in the former case ("progressive increase") or a restriction in the prevalence of cells expressing cholinergic properties in the other situation ("progressive restriction") results in the subpopulation-restricted expression of the respective characters observed at birth. Postnataly, population sizes may be altered to increase, such as the cholinergic neurons in sympathetic ganglia, or to decrease, such as the trkA-positive neurons in DRG.

\section{Functional analysis of GFL signalling in the sympathetic system}

Alterations in the peripheral sympathetic system of mice mutant for GFLs and their receptor subunits

Newborn mice lacking GDNF show a 35\%-40\% reduction of neuron number in the SCG (Moore et al. 1996). In addition, soma size is reduced. In contrast, for mutants of the GDNF receptor alpha subunit, GFRalpha1, the neuron number $(88 \%$ of wildtype) is not affected significantly (Enomoto et al. 1998). Moreover, soma cross sections are similar between 
Table 2 Onset of expression of receptors and function-specific markers during mouse embryogenesis (see text for references). Expression analysed by in situ hybridization (ISH), immunohistochemistry $(I H C)$ or detection of GFP expression from gene locus $(G F P)$

\begin{tabular}{ll}
\hline Receptor/marker & Embryonic day (method) \\
\hline $\begin{array}{l}\text { Dorsal root ganglia } \\
\text { ret }\end{array}$ & $<$ E11.5 (ISH/IHC) \\
GFRalpha1 & $<$ E13 (ISH) \\
GFRalpha2 & $<$ E13 (ISH) \\
GFRalpha3 & $<$ E13 (ISH) \\
TRPV1 & E13.5 (IHC) \\
TRPM8 & E16.5 (ISH/IHC) \\
Sympathetic ganglia & \\
ret & $<$ E11.5 (GFP) \\
GFRalpha1 & $<$ E12.5 (ISH) \\
GFRalpha2 & $<$ E12.5 (ISH) \\
GFRalpha3 & $<$ E12.5 (ISH) \\
ChAT & E10.5 (ISH) ${ }^{\mathrm{a}, \mathrm{b}}$ \\
VAChT & E10.5 (ISH) ${ }^{\mathrm{a}, \mathrm{b}}$ \\
\hline
\end{tabular}

$<$ Onset not precisely known; positive cells found at times indicated

${ }^{\text {a }}$ Postnatal increase in population size

${ }^{\mathrm{b}}$ Initially widely expressed; embryonic downregulation to neuronal subpopulation

${ }^{\mathrm{c}}$ After initial expression, completely downregulated during embryo-

mutant and wildtype mice. In newborn neurturin mutant mice, neuron profile counts (105\% of wildtype) and ganglion volume are not statistically different from wildtype (Heuckeroth et al. 1999). Likewise, in mutants of the neuturin receptor alpha subunit, GFRalpha2, no significant difference in SCG neuron number is detected as compared with adult wildtype animals (Rossi et al. 1999). Correspondingly, apoptosis as detected by activated caspase 3 is not increased in mutant ganglia at E15-P0 (Lähteenmaki et al. 2007). However, the soma size of VIP-immunoreactive neurons but not of TH-positive cells is reduced in GFRalpha 2 mutant mice (Hiltunen and Airaksinen 2004). In mice mutant for the artemin receptor subunit GFRalpha3, 40\%$50 \%$ cell loss is observed around birth (Nishino et al. 1999).

The data suggest that GFL signalling through GFRalpha receptors affects sympathetic neuron subpopulations and show a prominent survival effect only for GFRalpha3, and not for GFRalpha1 and GFRalpha2. The discrepancy between the effects of GDNF and its coreceptor GFRalphal may be attributable to alternative GDNF signalling pathways and warrants more detailed analysis.

Mutational inactivation of the ret gene affects sympathetic ganglion cell number in a complex manner by altering precursor migration, proliferation and cell survival

Mutant strains for ret have been generated by removing the tyrosine kinase domain (Schuchardt et al. 1994) and, alternatively, by replacing the first exon with a TGM reporter (Enomoto et al. 2001). Whereas initial reports from the kinase-deficient strain claimed a loss of the SCG but not of other sympathetic ganglia (Durbec et al. 1996), analysis of the TGM strain showed caudal displacement and a size reduction of the SCG in newborn animals (Enomoto et al. 2001). Even at E11.5, SCG primordia show a decrease in cell number by $\sim 30 \%$. Moreover, thoracic and lumbar sympathetic ganglia, including the STG, are reduced in size in newborn mutant mice (Enomoto et al. 2001). This has been confirmed for kinase-deficient mice in which the cell number in the STG is reduced by $24 \%$ in newborn animals and by $42 \%$ at E16 (Burau et al. 2004). The data show that

\section{embryonic}
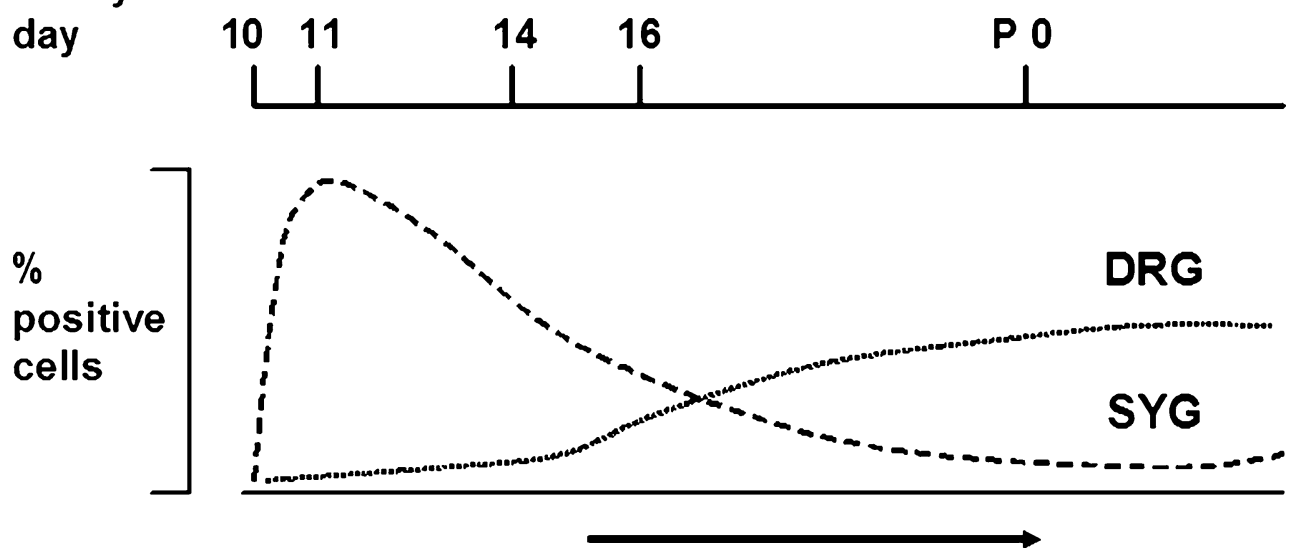

Fig. 4 ret expression in sympathetic ganglia $(S Y G)$ and dorsal root ganglia $(D R G)$ during mouse embryogenesis. ret is detected in SYG and DRG during embryonic day 11 . Whereas expression in DRG is initally restricted to few neurons of large diameter, expression in SYG is found at this stage throughout the ganglion. During the third week of embryonic development, an increasing number of small neurons in DRG initiates ret expression, while expression in sympathetic ganglia is restricted to a subset of neurons thus distinguishing a "progressive increase" from a "progressive restriction" of gene expression to neuron subpopulations (arrow NGF requirement for the increase in the ret-positive population in DRG) 
embryonic
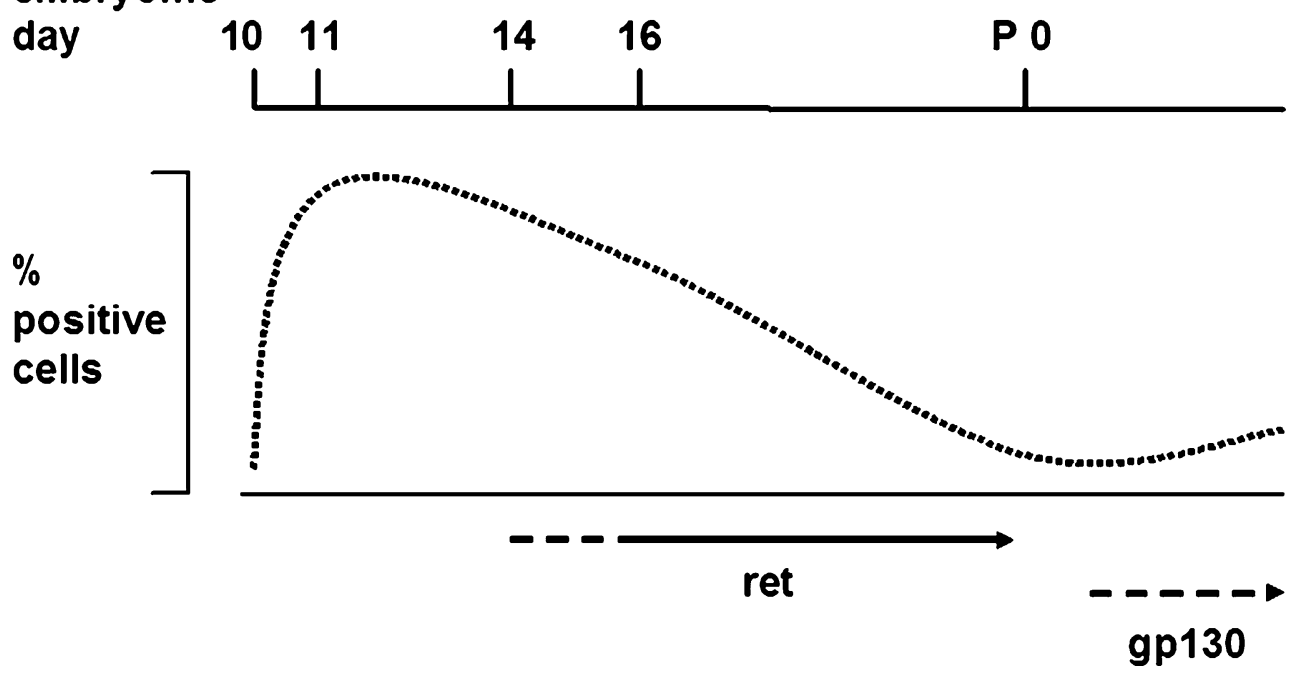

Fig. 5 Cholineric differentiation of sympathetic neurons during mouse embryogenesis. Initiation of cholinergic differentiation occurs during embryonic day 11 when ChAT and VAChT mRNA is first detectable by in situ hybridization. The majority of neurons rapidly become positive for the cholinergic markers. After embryonic day 14, most cells lose ChAT and VAChT expression. A small percentage of

sympathetic ganglion cell number in ret mutant mice is affected even at early embryonic stages and from cervical to lumbar levels.

The increase in pyknotic cells in SCG and STG of newborn animals and at E16.5 in STG shows that cell death contributes to neuronal cell loss in ret mutant mice during the third week of embryonic development to birth (Enomoto et al. 2001). Surprisingly, the dying cell population (positive for activated caspase 3 ) and the ret-positive (TGM-expressing) population are largely non-overlapping. No selective elimination of the ret-positive cell population by the ret mutation has been concluded to occur, which is supported by the similar proportion of TGM-reporter-expressing cells in heterozygous and homozygous mutant mice (Enomoto et al. 2001).

No increase in cell death is observed in SCG and STG of mutant animals at E10.5-E13.5. In addition, the size of the BrdU-positive proliferating population is comparable at E11.5 between wildtype and mutant mice (Enomoto et al. 2001). Thus, the reduced cell number in SCG at early developmental stages seems to be attributable to deficits during the migration period rather than to alterations in cell survival or proliferation after ganglion formation. At E16.5, however, cell proliferation is found in SCG and STG of ret mutants but not wildtype animals (Enomoto et al. 2001) indicating an extended proliferation period in mutant animals. Together with the observation of neuroblast-like morphology (Enomoto et al. 2001) and reduced cell size (Burau et al. 2004) at E16.5, the finding suggests a delayed differentiation in mutants. The prolonged proliferation period may account for the decrease in the relative loss of STG cells from E16.5 to P0 (see above). neurons remains positive at birth; this depends on ret tyrosine kinase activity. After birth, gp130 signalling is required for the postnatal increase in the number of cholinergic cells (arrow period of ret dependence, dotted lines onset of ret and gp130 dependence, which are not precisely determined). Percentage of positive cells is given as relative values

Taken together, a complex set of alterations accounts for the decreased sympathetic neuron number in ret mutant mice. A migration-related deficit leads to reduced cell numbers in the newly formed SCG during the second embryonic week. No alteration in apoptosis and proliferation is detected at this stage but is found at later stages. Increased proliferation and cell death occurs in the STG during the third week of embryonic development.

GFRalpha3 mutants show altered SCG position and cell number attributable to migration, proliferation and survival effects

Sympathetic development has been analysed in detail in three strains of GFRalpha3 mutant mice. The first has exons 4 8 removed (Nishino et al. 1999), whereas in the second, taulacZ is introduced in exon 1 (Honma et al. 2002) and, in the third strain, exon 1 is replaced by a PGK1-neo cassette (Andres et al. 2001). In all strains, homozygous animals show a size reduction and caudal shift of the SCG at E12.5 (Nishino et al. 1999) and E14.5 (Andres et al. 2001) and in adult animals (Honma et al. 2002). In addition, thoracic ganglia are invariably smaller and aberrantly segmented, as analysed in adult and newborn GFRalpha3 and artemin mutant animals (Honma et al. 2002).

In both types of mutants, ptosis is reported to correlate with the size reduction or loss of the SCG. In the tau-lacZ [exon1] animals, ptosis is observed in $30 \%$ of adult homozygous mutants (Honma et al. 2002). Identical percentages of animals with uni- or bilateral ptosis are reported for mice with a mutation in the gene coding for the GFRalpha3 ligand 
artemin. In the affected animals, the SCG ipsilateral to the eye showing ptosis is missing $(30 \%)$ or reduced in size (70\%). In adult animals without ptosis, SCG show normal cell numbers (Honma et al. 2002). For the [exon 4-8] removal mutants, more dramatic effects on the SCG are reported: the cell number at P60 is only $0 \%-5 \%$ of that in wildtype (Nishino et al. 1999).

In [exon 4-8] removal mutants, cell numbers have been quantified during development (Nishino et al. 1999). Although no difference in SCG cell number is reported at E11.5, E12.5 mutants have 70\%, E14.5 60\% and P7 50\% of the wildtype cell number. TUNEL staining at P5 indicates the involvement of cell death at least postnatally. For STG, the mutant cell number is reported to be higher than that in wildtype at E12.5 (140\%) and no different from wildtype at E14.5 (Nishino et al. 1999). The reduced number of SCG neurons during embryonic development has been confirmed at E14 in the PGK-neo [exon1] mouse (Andres et al. 2001). In this mutant, evidence for a reduction in neuroblast proliferation has been provided. IHC for the proliferation marker proliferating nuclear cell antigen (PCNA) shows a reduction of $\sim 50 \%$ of PCNA-immunoreactive $\beta$ III-tubulinpositive cells at E14. These studies indicate that the reduction in SCG cell numbers is attributable to altered proliferation during embryogenesis and cell death postnatally. The difference between cell number in SCG and STG at E14.5 suggests additional effects of the GFRalpha3 mutation on cell migration.

Quantification in the tau-lacZ [exon1] mutants differs in some detail (Honma et al. 2002). At E10.5, sympathetic precursors adjacent to the dorsal aorta at forelimb levels are reduced by $\sim 20 \%$ relative to wildtype animals. At E12.5 neuroblast numbers in the SCG of mutant animals are $~ 90 \%$ of wildtype (Honma et al. 2002). No increased apoptosis has been reported during embryogenesis. At $\mathrm{P} 0$, increased apoptosis is found in SCG of artemin mutant mice when the position of the ganglion is shifted, but not in normally positioned ganglia. BrdU labelling provides no evidence for effects on proliferation at E11.5-E14.5 in the GFRalpha3 [exon 4-8] removal mutants or the artemin mutants (Honma et al. 2002). This second data set suggests that early embryonic SCG development is affected by GFRalpha3 effects on cell migration rather than survival and proliferation.

Mutational analysis shows effects of GFL signalling on sympathetic target innervation

Severe deficits in sympathetic axonal projections are reported in ret TGM mice (Enomoto et al. 2001). In newborn mutants, projections from the SCG via the internal carotid nerve are attenuated and show abnormal branching. Sympathetic fibres in rostral facial structures such as the eyes, nasal mucosa and skin are almost completely depleted. Innervation density in the submandibular gland of mutant animals never reaches normal levels. The vertebral nerve as a major trunk projecting from the STG is also reduced. In addition, sympathetic projections from prevertebral ganglia such as branches along the superior mesenteric artery are depleted. Even at E10.5, fewer sympathetic cells extend long neurites in mutant mice as compared with wildtype animals (Enomoto et al. 2001). Impaired axonal projections become more obvious in the SCG, STG and prevertebral ganglia at E12.5-E13.5. At E15.5, rostral projections from the SCG to form the internal carotid nerve are thin. In two out of four animals, nerve bundles project in the wrong direction.

In GFRalpha3 [exon 4-8] removal mutants, TH-positive fibres are lost in the submandibular gland and the superior tarsus muscle of adult animals and at P1 (Nishino et al. 1999). In the tau-lacZ [exon1] mutants, abnormal innervation of the superior tarsus muscle is observed only in animals showing ptosis and abnormal or missing SCG (Honma et al. 2002). The gut, receiving TH-positive fibres from prevertebral sympathetic ganglia, shows reduced innervation in mutant mice with specific loss in circular muscle layers of the oesophagus, stomach and intestine. In these and artemin mutants, failure to form normally fasciculated axon bundles is reported. As early as E12.5 and E13.5, axonal outgrowth from the SCG and prevertebral ganglia is abnormal (Honma et al. 2002). Interestingly, axonal outgrowth deficits are apparent in all mutant embryos.

In GDNF mutant mice, TH immunostaining as an indicator of sympathetic innervation is reduced in blood vessels and glands in the head (Granholm et al. 1997). In parallel, a clear reduction of the TH signal is reported in the SCG. In GFRalpha1 mutant mice, however, the innervation of facial blood vessels as analysed by TH IHC is equivalent to that of wildtype animals (Enomoto et al. 1998).

In GFRalpha2 mutant mice, a profound reduction in innervation density is found in targets of cholinergic, but not noradrenergic, sympathetic fibres (Hiltunen et al. 2000; Hiltunen and Airaksinen 2004; Rossi et al. 1999). Immunostaining for VAChT and the neuropeptide VIP has been used for cholinergic markers, with TH IHC as a noradrenergic indicator. The difference in density of cholinergic sweat gland innervation between wildtype and mutant animals manifests during postnatal development as analysed at P21 (Hiltunen and Airaksinen 2004). The early innervation pattern by noradrenergic fibres at P4 shows no difference from wildtype.

Mutational inactivation of ret leads to an almost complete loss of cholinergic markers in newborn sympathetic ganglia

In prehatching chick embryos, ret mRNA expression in paravertebral sympathetic ganglia is highly colocalized with the cholinergic marker peptide VIP (Ernsberger et al. 1997). 
This has prompted the hypothesis that ret signalling is involved in the development of cholinergic sympathetic neurons. Analysis of tyrosine kinase-deficient ret mutant mice by ISH shows a massive loss of ChAT and VAChT mRNAs in sympathetic ganglia (Burau et al. 2004). Compared with wildtype, the number of positive cells is reduced by more than $90 \%$ in newborn mutant STG. As early as E16, cholinergic marker expression is affected by the ret mutation. The number of STG cells with strong expression of ChAT and VAChT mRNAs is reduced in mutant animals by more than $80 \%$. Cells showing low levels of expression of VAChT mRNA at this stage, however, are only moderately reduced in mutant mice, similar to the total cell population. At E13 and E14, when many STG cells express ChAT and VAChT mRNAs at low levels, no reduction of the cholinergic markers is observed by ISH in mutant mice (Burau et al. 2004). The data show that ret is required for the development of cholinergic sympathetic neurons at advanced developmental stages but not for the induction of ChAT and VAChT expression early during embryonic development. The way in which ret affects the development of cholinergic neurons still has to be clarified. Since ret-expressing cells are not preferentially lost in ret mutant mice (Enomoto et al. 2001) and ret is expressed in cholinergic cells in chick sympathetic ganglia (Ernsberger et al. 1997), the loss of ChAT- and VAChT-positive sympathetic cells in ret mutants may be attributable to an altered regulation of cholinergic gene expression rather than the loss of cells by cell death. Whether this effect is directly mediated by ret signalling or indirectly, for example, via axonal outgrowth and access to other growth factors also remains to be clarified. In explant cultures of sympathetic ganglia from E12 chick embryos, GDNF and neurturin increase ChAT mRNA levels as detected by RT-PCR (Brodski et al. 2002). However, whether this is attributable due to selective survival or induction of gene expression is unclear.

In GFRalpha2 mutants, where the innervation of two targets of cholinergic sympathetic neurons, viz. the periosteum and sweat glands in foot pads, is compromised, the number of neurons expressing the cholinergic marker peptide VIP is not significantly altered (111\%) compared with wildtype (Hiltunen and Airaksinen 2004). The data suggest that this mutation does not affect the expression of a neuropeptide characteristic for cholinergic sympathetic neurons. Whether ChAT and VAChT expression is affected remains to be analysed.

Summary of analysis in sympathetic neurons

\section{ret and GFRalpha expression}

In sympathetic ganglia of mouse embryos, widespread ret expression can be detected at E11.5. This expression is restricted to a subpopulation of sympathetic neurons at birth. GFRalpha1-3 are detectable at E12.5 but the onset of ex- pression is unclear. With ongoing development, GFRalpha1 is lost from sympathetic neurons, whereas GFRalpha 2 and 3 are restricted to neuron subpopulations.

\section{Sympathetic ganglion cell number}

In ret mutant mice, sympathetic ganglion cell number is reduced even at E11.5 by $30 \%$ as compared with wildtype. This may be attributable to an effect during precursor migration to the ganglionic sites. At E16.5, increased apoptosis and increased proliferation occurs in mutant sympathetic ganglia demonstrating the complex action of ret signalling on sympathetic neuron number. In newborn mutant animals, STG neuron number is $24 \%$ smaller than that in wildtype.

In artemin and GFRalpha3 mutant animals, cervical and thoracic sympathetic ganglia are reduced in size. For GFRalpha3 mutants, approximately $50 \%$ cell loss is reported for the SCG at birth, with effects on migration, proliferation and survival being documented. Since cell loss is observed only when ganglia are displaced and enhanced apoptosis is detected postnatally and not embryonically, it may occur secondary to disturbed target innervation and access to targetderived survival factors. In contrast, neither newborn neurturin mutants nor adult GFRalpha2 mutants have revealed significant changes in sympathetic neuron number. For GDNF (but not GFRalpha1) mutants, approximately $40 \%$ cell loss is reported.

Thus, mutant analysis shows multiple effects of ret signalling on sympathetic neuron number. The artemin/GFRalpha3 pathway and GDNF, but not GFRalpha1 or neurturin/ GFRalpha2, appear involved.

\section{Neurite outgrowth}

ret mutants show altered outgrowth of sympathetic neurites as early as E10.5. Alterations include erroneous direction of growing neurites indicating effects on pathway choice. GFRalpha3 also affects neurite outgrowth emphasizing the importance of this signal transducer for various aspects of sympathetic development. For GFRalpha2, which has no major effect on sympathetic neuron number, a reduction of innervation in targets of cholinergic sympathetic neurons is found.

\section{Transmitter phenotype}

Coexpression of ret with cholinergic properties in chick sympathetic neurons has suggested the involvement of ret signalling in the development of this neuronal subset. This has been confirmed in newborn ret mutant mice, which almost entirely lose the expression of ChAT and VAChT mRNAs in sympathetic ganglia. The persistence of GFP-positive neurons in mutant mice in which the ret coding sequence is replaced 
by GFP suggests that the potentially cholinergic cells are not lost but lack gene expression from the cholinergic locus.

The effect of ret mutation becomes apparent when the initially widespread expression of the cholinergic markers becomes restricted to a small subset of cells during the third week of embryonic development. The observations establish different stages of transmitter phenotype specification characterized by changing growth factor requirements and increasing restriction of gene expression patterns. The initial expression of cholinergic properties in a large proportion of sympathetic neurons from E10.5 to E14.5 is ret-independent. The restriction of cholinergic properties to a small subpopulation of neurons that occurs until birth requires ret.

\section{Role of GFLs and their receptors in DRG neuron development}

Analysis of mutant mice

The data available for mice mutant in the GFL or GFRalpha genes are currently limited. Neonatal GDNF mutant animals show a $23 \%-28 \%$ reduction in neuron numbers in L5 DRG as determined with two different counting methods (Moore et al. 1996). Cell area measurements in the mutant animals are shifted to larger sizes (Baudet et al. 2000) indicating that small neurons may be lost preferentially. In neonate GFRalpha1 mutant animals, however, no cell loss is reported in L5 DRG (Cacalano et al. 1998) and neurons appear histologically normal (Enomoto et al. 1998). Since the survival effects of GFLs in cell culture become apparent at postnatal stages (Baudet et al. 2000), the analysis of mutant mice after birth seems relevant. Homozygous GDNF and GFRalphal mutant animals, however, die within the first 1.5 days after birth. On the other hand, mice with homozygous mutations of artemin or GFRalpha3 survive to adulthood. DRG of adult artemin mutant mice are of normal size and morphology (Honma et al. 2002). No deficits are apparent in IB4 binding or CGRPimmunoreactive neurons. Similarly, the total number of neurons in DRG of GFRalpha3 mutant mice is normal at all stages analysed (which are not further specified) and the percentage of CGRP-immunoreactive neurons is unaltered in adult animals (Nishino et al. 1999). In neurturin mutant mice, the number of GFRalpha2-positive cells is reduced by $45 \%$ in adult L4 DRG (Heuckeroth et al. 1999). However, whether this is attributable to the loss of neurons or of expression is unclear. In GFRalpha2 mutant mice, DRG appear of normal size (Rossi et al. 1999) and apoptosis, as determined by activated caspase $3 \mathrm{IHC}$, is not significantly different from wildtype DRG at E15-P0 (Lähteenmaki et al. 2007). In the saphenous nerve of these animals, no loss of myelinated or unmyelinated axons is observed (Stucky et al. 2002) suggesting that neuron numbers in GFRalpha2 mutant animals may be unaltered. ret appears not to be required for cell viability but for TRPA1 expression

In P14 ret mutant animals, cell counts in L5 DRG sections are only $15 \%$ reduced compared with controls (Luo et al. 2007). No cell loss is detected after counting the cells of dissociated ganglia, leading the authors to conclude that ret is not required for cell viability. In addition, the proportion of different sensory populations, in particular those expressing CGRP, is unaltered. Cell size, however, is affected in a populationspecific manner. Peripherin-immunoreactive neurons are reduced in size, whereas CGRP-positive and neurofilament200-immunoreactive cells appear normal, indicating that nonpeptidergic neurons are affected. Peripheral target innervation is also altered in a population-specific manner. In the skin, substantial reduction of non-peptidergic fibres is found in the epidermis, whereas CGRP-positive innervation appears normal. In contrast, the lamina-specific distribution of peptidergic and non-peptidergic innervation in the spinal cord appears unaffected. The expression of TRP channels is selectively altered in mutant DRG neurons. TRPA1 mRNA expression is completely absent from P14 ret mutant DRG, whereas mRNAs for TRPV1 and TRPM8 appear unaffected. The authors conclude that ret controls the expression of a subset of genes characteristic of mature non-peptidergic nociceptors (Luo et al. 2007).

\section{GFRalpha2 mutation affects cold sensitivity in vivo and heat sensitivity in vitro}

In GFRalpha2 mutant mice, axon diameters are reduced in the saphenous nerve (Stucky et al. 2002) and IB4-binding DRG neuron profiles are reduced in size (Lindfors et al. 2006). In contrast, CGRP-immunoreactive neurons show a normal size distribution in GFRalpha2 mutants. Correspondingly, the density of CGRP-positive fibres in mutant epidermis appears normal, whereas the density of neuron-specific protein gene product 9.5 (PGP9.5)-positive CGRP-negative fibres is reduced by $\sim 70 \%$. The subepidermal nerve plexus in footpad dermis shows unaltered fibre density. The central projection of IB4-positive fibres to lamina II in the spinal cord appears normal. Behavioural testing of GFRalpha2 mutant mice shows normal behaviour to tactile stimulation and to innocuous temperatures and hot-plate testing. However, in cold water, withdrawal occurs with much shorter latencies and formalin-induced persistent pain is reduced in mutants (Lindfors et al. 2006).

In an in vitro saphenous nerve skin preparation, all subtypes of cutaneous neurons are present with myelinated axons in normal numbers and a normal mechanical response (Stucky et al. 2002). In dissociated culture from adult DRG neurons, heat-induced inward currents have been recorded from small-diameter neurons presumably corresponding to 
unmyelinated afferents. The percentage of IB4-binding neurons with large heat-induced currents drops from $47 \%$ in cultures from wildtype animals to $12 \%$ in those from GFRalpha2 mutant mice (Stucky et al. 2002).

Thus, GFRalpha2 mutants require more analysis to provide details regarding the alterations in afferent neuron physiology and in TRP channel expression that may underlie the behavioural phenotype. Comparison with mice having altered neurturin expression should provide a clearer picture of the role of neurturin and GFRalpha2 signalling in the differentiation of the thermosensitive properties of DRG neurons.

Analysis in GFL-overexpressing mice

\section{Overexpression of GDNF in mouse skin increases mechanical sensitivity of $C$ fibres}

Overexpression of GDNF in transgenic mice under control of the K14 keratin gene promoter results in a six-fold increase of GDNF protein in skin (Zwick et al. 2002). DRG neuron counts in adult L4/5 ganglia increase by $27 \%$ with a preferential effect on small ret-positive and IB4-binding neurons. The number of ret-expressing cells increases from $40 \%$ of DRG neurons in wildtype to $55 \%$ in transgenic animals and IB4-binding cells increase from $33 \%$ in wildtype to $49 \%$ in GDNF-overexpressing animals. In the saphenous nerve, the number of myelinated axons increases by $26 \%$ and that of unmyelinated axons by $72 \%$. No change is observed in the percentage of CGRP- or TRPV1-positive neurons and the overlap with IB4 expression is also unaltered. In transgenic skin, particularly the epidermis, the density of PGP9.5-labelled fibres is increased. Central IB4-positive projections are enhanced, whereas the thickness of CGRP and TRPV1 bands in lamina 1 is unaltered. Behaviour to noxious heat and to mechanical stimulation with von Frey hairs is unaltered in GDNF-overexpressing mice (Zwick et al. 2002). However, the mechanical sensitivity of $C$ fibres is affected.

Intracellular recording and labelling of DRG neurons in an ex vivo preparation of spinal cord, DRG, nerves and dorsolateral skin (Albers et al. 2006) shows 68\% (11/16) of $\mathrm{C}$ fibre soma to be IB4-positive in wildtype mice, whereas all 20 cells recorded from GDNF-overexpressing animals are IB4-positive. In wildtype animals, 25\% (2/8) of the neurons are CGRP-immunoreactive with no overlap to IB4-binding cells, whereas $14 \%(1 / 7)$ of the IB4-positive cells recorded from GDNF-overexpressing mice are also CGRP-positive. No obvious difference is found in the central projection pattern of individual afferents retrogradely labelled with Neurobiotin. C fibre units in transgenic animals show no difference in somal spike properties and resting membrane potential but significantly faster conduction velocities. Importantly, mechanical thresholds are significantly decreased. All of the $\mathrm{C}$ fibres with low-threshold mechanoreceptors (LTMR) in transgenic back skin respond to noxious heat, whereas LTMR in wildtype are not heat-responsive. This shows a novel $\mathrm{C}$ fibre phenotype in GDNF-overexpressing mice. Since their action potential duration is no different from high-threshold mechanoreceptors (HTMR) and since $\mathrm{C}$ fibres with LTMR are infrequent in wildtype back skin, they may be derived from HTMR by lowering the mechanical threshold. Analysis of the expression of putative mechanosensitive ion channels by RT-PCR shows increased mRNA levels for acidsensitive ion channel 2a (ASIC2a) and ASIC2b but not for ASIC1 and ASIC3 in GDNF-overexpressing animals. ASIC2 IR increases in small- but not large-diameter DRG neurons and double-labelling shows the increase to occur preferentially, but not exclusively, in IB4-binding cells (Albers et al. 2006). Of $\mathrm{C}$ fibres in wildtype back skin, $81 \%(21 / 26)$ respond to noxious heat, whereas $97 \%(35 / 36)$ are heatsensitive in GDNF-overexpressing animals, heat threshold and firing frequency however being unaltered. As all units tested $(n=5)$ are acid-sensitive, they are classified as polymodal nociceptors. Ganglionic TRP channel mRNA levels analysed by RT-PCR demonstrate a 1.5 -fold increase for the cold receptors TRPA1 and TRPM8, a 1.5-fold decrease for the heat receptor TRPV1 and no change in TRPV2, V3 and V4 when normalized against the housekeeping gene D-glyceraldehyde-3-phosphate dehydrogenase.

Thus, the number of small ret-positive DRG neurons increases in GDNF-overexpressing mice. In addition, the mechanical thresholds of $\mathrm{C}$ fibre units decrease and ASIC2 expression is increased at the RNA and protein levels. However, in behavioural tests, no mechanical hyperexcitability is observed. Because of the six-fold increase of GDNF protein in skin and the possible weak interaction of GDNF with GFRalpha2 and 3 (for a review, see Airaksinen and Saarma 2002) in addition to its signalling via GFRalpha1, receptor crosstalk may be involved in these alterations. The different effects of artemin overexpression (see below) make it unlikely, however, that GFRalpha3 is significantly involved in the effects of increased GDNF availability.

\section{Artemin-overexpressing animals show increased C fibre heat sensitivity}

In transgenic mice overexpressing artemin under the control of the K14 keratin gene promoter in skin, increased RNA and protein levels are detected by RT-PCR and by immunolabelling (Elitt et al. 2006). The neuron number in L4 DRG is increased by $21 \%$ compared with wildtype, the percentage of GFRalpha3-positive neurons being unchanged at $18 \%$ in transgenic animals compared with $20 \%$ in wildtype. Normalized mRNA levels for GFRalpha3, however, are increased by $34 \%$, indicating increased expression levels in positive cells. Surprisingly, ret transcript levels are unchanged, 
whereas trkA mRNA levels increase by 37\%. PGP-9.5 IHC shows no major change of innervation density and pattern in skin. GFRalpha3- and TRPV1-immunoreactive fibres, however, are increased in number. Correspondingly, TRPV1 transcript levels are increased by $61 \%$ (RT-PCR), whereas TRPV2, V3 and V4 transcripts are unchanged. The percentage of TRPV1-positive cells is no different in transgenic animals ( $29 \%$ compared with $28 \%$ in wildtype) and overlap with GFRalpha3 expression is nearly complete. Some $94 \%$ of wildtype and $97 \%$ of transgenic GFRalpha3-positive cells are TRPV1-immunoreactive (Elitt et al. 2006). TRPA1 is expressed by nearly all GFRalpha3- and TRPV1-positive neurons. TRPA1 mRNA levels are increased by $210 \%$ (RTPCR) and IR in ganglion sections is more intense. Transcript levels for ASIC1, 2a, 2b and 3 are decreased in female transgenic mice and ASIC2a is decreased in males.

In an ex vivo preparation of skin, saphenous nerve, DRG and spinal cord, the mechanical thresholds of $\mathrm{C}$ fibres and mean firing rates after mechanical stimulation appear unchanged. Heat thresholds are decreased, however, and firing rates upon thermal stimulation are increased (Elitt et al. 2006). Correspondingly, transgenic animals show no difference in behavioural response to mechanical stimulation but an increased heat and cold immersion response correlating with increased TRPV1 and TRPA1 expression, respectively.

In vitro studies show that GDNF can regulate expression of SP, voltage-gated sodium channels and TRPV1

In vitro studies on adult rodent DRG neurons show that GDNF, similar to NGF, may affect the expression of neuropeptides and ion channels.

In dissociated rat DRG neurons grown for 1 week in culture, GDNF increases SP levels as analysed by radioimmunoassay (Skoff and Adler 2006). The percentage of preprotachykinin mRNA-positive neurons and the number of SP-immunoreactive cells are increased (Ogun-Muyiwa et al. 1999). The effect is somewhat smaller than that caused by NGF, with the addition of both NGF and GDNF having no additive effects.

Expression of mRNAs for SNS and NaN voltagedependent sodium channels in cultures of DRG neurons is restored by GDNF, whereas NGF is reported to rescue downregulation of SNS, not NaN (Fjell et al. 1999c). GDNF in contrast to NGF causes an increase in the peak amplitude of the TTX-resistant sodium current in these cells.

The capsaicin response and TRPV1 expression is affected by GFL growth factors in short-term and extended cultures. Within minutes of application, GDNF, neurturin, artemin and NGF potentiate the capsaicin response of mouse DRG neurons as analysed by calcium imaging in short-term ( 1 day) culture (Malin et al. 2006). Interestingly, GDNF neither increases the percentage of heat-responsive neurons nor the heat-induced current in culture (Stucky and Lewin 1999). In contrast, NGF increases the proportion of IB4positive and -negative neurons that repond to heat. In corresponding cultures of adult rat DRG neurons, GDNF increases capsaicin-induced cobalt uptake (Ogun-Muyiwa et al. 1999; Bron et al. 2003). After extended culture periods (1 week), TRPV1 mRNA levels are increased and a higher number of positive cells is maintained (Ogun-Muyiwa et al. 1999). The GDNF-induced increase in TRPV1 IR in longterm culture is similar to that affected by NGF (Bron et al. 2003). After inflammation induced by complete Freund adjuvant, the percentage of trkA-positive and IB4-positive cells that express TRPV1 increases in vivo (Amaya et al. 2004). The increase in the trkA-positive population can be blocked by anti-NGF antibodies and that in the IB4-positive population by anti-GDNF.

Thus, the culture studies strongly suggest that GDNF has the potential to regulate directly the expression of neuropeptide and ion channel genes in DRG neurons. In vitro, GDNF increases the proportion of neurons positive for SP and TRPV1, markers for nociceptor subpopulations. The downregulation of TRPV1 by overexpression of GDNF in vivo demonstrates, however, that regulatory processes in culture cannot be easily extrapolated to the situation in situ.

Summary of analysis in DRG neurons

\section{Expression of ret and GFRalpha receptor subunits}

ret expression in mouse DRG is detectable as early as E11 in a small number of neurons. Although these cells are trkB-positive, an increasing population of trkA-positive cells expresses ret during the third embryonic week. Postnatal loss of trkA in a subset of DRG neurons results in the presence of a large population of small ret-positive, IB4-positive and trkA-negative nociceptors in mature DRG. In addition, a less-well-characterized population of largediameter ret-positive neurons exists.

The developmental onset of GFRalpha receptor subunits in DRG has not been analysed in detail. Low level expression is detected at E13 and expression increases until birth and postnatally. In the trigeminal ganglion of mouse embryos, GFRalpha1 and GFRalpha2 mRNAs can be detected by ISH preceding ret expression (Luukko et al. 1997).

In adult rats, more than half of the ret-positive DRG cells express GFRalpha1 and one third GFRalpha2. Another third of ret-positive cells expresses GFRalpha3. The large majority $(>70 \%)$ of the GFRalpha3-positive cells express trkA, CGRP and TRPV1 defining a peptidergic ret-positive nociceptor population in contrast to the larger proportion of non-peptidergic ret-positive nociceptors. The majority of GFRalpha2-positive cells constitutes a population of small non-peptidergic neurons. 


\section{Effect on DRG neuron numbers}

Even though GFLs have been isolated by means of their survival effects in vitro, cell death is not a prominent feature in DRG of mutant mice in vivo. In ret mutants, no neuron loss is reported from P14 DRG. Artemin and GFRalpha3 mutant mice have adult DRG neuron counts no different from those of wildtype animals, even though artemin-overexpressing animals show a $20 \%$ increase in neuron number. For neurturin and GFRalpha2 mutants, no DRG neuron counts are available. Normal axon counts in the saphenous nerve of GFRalpha2 mutants indicate that this signalling pathway may not be important for DRG neuron survival either. Data on neurturin-overexpressing mice are currently unavailable. For newborn GDNF mutant animals, a loss of a quarter of the L5 DRG neurons is reported, which, however, is not observed in GFRalpha1 mutants. In GDNF-overexpressing animals, neuron number in L4/5 DRG increases by a quarter.

\section{Effects of GFL signalling on afferent properties}

GFL overexpression and GFRalpha mutation affect the mechanical and thermal responsiveness of sensory neurons. In the case of GDNF overexpression in skin, the mechanical thresholds of $\mathrm{C}$ fibre afferents decrease, with LTMR showing a heat responsiveness not observed in wildtype animals. In artemin-overexpressing mice, heat thresholds of $\mathrm{C}$ fibre units are reduced, whereas mechanical sensitivity appears unaltered. Neurturin may likewise affect heat-sensitivity since heat-evoked currents are reduced in cultured small neurons from GFRalpha2 mutant animals.

\section{Regulation of channel expression}

TRP channels are targets of GFL signalling. TRPA1 mRNA expression is abolished in ret mutant DRG analysed at P14. In mice overexpressing GDNF or artemin, TRPA1 mRNA levels in DRG are increased and correlate with an increased cold immersion response in artemin-overexpressing animals. Data for neurturin-overexpressing mice are currently not available. The picture is less consistent for TRPV1. Whereas TRPV1 expression is reduced in GDNF-overexpressing animals, mRNA levels (but not the percentage of positive cells) are increased in DRG of artemin-overexpressing mice. GDNF application to cultured rat DRG neurons maintains elevated expression levels. TRPV1 expression in ret mutant mice appears unaffected. Thus, for GDNF, a direct action on TRPV1 expression seems possible, although its role in vivo is unclear.

For ASIC2 expression, a strong effect of GDNF overexpression in vivo is observed and correlates with alterations in mechanical sensitivity of $\mathrm{C}$ fibres. Whether this is attributable to the direct regulation of ASIC expression remains to be resolved.
Sensory phenotype specification

The recent results showing that mutation of the ret gene does not alter the major subtype composition of DRG neurons and, in particular, does not change the proportion of CGRPpositive neurons in a major way suggest that ret signalling is not essential for the gross segregation of DRG neuron lineages. However, ret mutation compromises, but does not prevent, the loss of trkA expression in a subset of DRG neurons. In addition, ret mutation leads to a reduction of GFRalpha1 and GFRalpha2, but not GFRalpha3, expression. The results show that ret promotes the generation of trkAnegative nociceptors and GFRalpha1- and GFRalpha2positive DRG neuron populations.

The effects of the ret mutation on TRP channel expression reveal the regulation of subsets of genes expressed in nociceptor populations. The expression of these channels is, however, not restricted to either peptidergic or non-peptidergic nociceptors. Approximately half of the TRPV1-expressing cells are trkA-positive and half express ret in rats. Mouse ret mutants show unaltered TRPV1 expression, whereas TRPA1, which is coexpressed with TRPV1 in rat, is lost from mutant DRG. The observation suggests that ret signalling is not required for the generation of a TRPV1-positive nociceptor subclass but for the expression of an additional differentiation marker, TRPA1.

The appearance of a novel class of heat-sensitive LTMR in GDNF-overexpressing mice might be a modulation of mechanical threshold in HTMR. The molecular nature of this change is of interest since it may shed light on the possibility of transition from HTMR to LTMR.

\section{Conclusions and perspectives}

ret and GFRalpha expression

ret expression is regulated differently during the development of mouse sympathetic and sensory ganglia. Although initiation of expression in DRG is found at E11.5 in a small number of neurons that increases during embryonic and postnatal development, all sympathetic neurons are positive at E11.5 and their proportion is downregulated to a subpopulation at birth (Fig. 4 and compare Fig. 2 for E13.5 and P0).

The ret-positive neuron population entails cholinergic neurons in sympathetic ganglia and non-peptidergic nociceptors in DRG. The generation of the bulk of ret-positive cells in DRG requires NGF signalling as shown in NGF/Bax doublemutant mice. Only a small early ret-expressing population of DRG neurons is NGF-independent. In sympathetic neurons, ret expression is detected before trkA expression and appears correlated with trkC expression instead. The importance of trkC signalling for ret expression in vivo remains to be determined. 
The expression of GFRalphas marks the development of sensory and sympathetic neuron subpopulations whose properties and target tissues are not fully defined. GFRalpha3-positive DRG neurons constitute a population of trkA and ret-positive peptidergic afferents. Their generation seems independent of ret and NGF signalling. In contrast, GFRalpha1- and GFRalpha2-positive DRG neurons depend on both signalling pathways. GFRalpha1-expressing DRG neurons are absent in newborn NGF/Bax mutant mice and GFRalpha2 expression is strongly reduced. Moreover, in ret mutant mice, the expression of GFRalpha1 and GFRalpha2 is reduced in DRG. These studies have been taken to indicate that NGF and ret signalling are involved in the initiation of expression and later differentiation of the specific subpopulations, respectively. However, as GFRalpha expression is initiated in the second embryonic week, lack of GFRalpha expression in newborn NGF/Bax mutant animals might not provide a reliable picture of signalling requirements during initial differentiation. For the cholinergic transmitter phenotype in sympathetic neurons, a succession of differentiation stages with changing growth factor requirements during embryonic development has been shown where expression is absent from ganglia of neonatal ret mutant mice but initiation of expression during embryogenesis is unaffected by the mutation.

\section{Sympathetic transmitter phenotype}

In sympathetic neurons of mammals and birds, noradrenergic differentiation is initiated early during neuronal differentiation under the control of bone morphogenetic protein growth factors (for reviews, see Ernsberger and Rohrer 1996; Ernsberger 2000; Goridis and Rohrer 2002) and is followed by cholinergic differentiation. The signals involved in the induction of gene expression from the cholinergic locus during the second embryonic week are not yet characterized. After the ret-independent initial induction of ChAT and VAChT expression in the majority or even all sympathetic neurons, the cholinergic markers are lost in most cells and become expressed at comparatively high levels in a small subset of sympathetic neurons (Fig. 5). The segregation of cholinergic gene expression to a neuronal subpopulation occurs during the third embryonic week in mouse development and ret signalling is indispensable for this process. In newborn ret mutant animals, expression of ChAT and VAChT is largely undetectable indicating that the downregulation of cholinergic gene expression has occurred but that development of the remaining cholinergic neuron population is disturbed. Available evidence suggests that this is not attributable to cell loss but to altered marker expression. Whether ret signalling acts directly via the regulation of gene expression or indirectly via the promotion of neurite outgrowth and access to other cholinergic differentiation signals remains to be resolved. Moreover, the ligands involved in the observed effects have to be determined. The postnatal increase in the number of cholinergic sympathetic neurons depends on gp130 signalling (Stanke et al. 2006). Whether ret signalling is also involved in the development of cholinergic neurons postnatally needs to be clarified.

\section{Afferent properties of DRG neurons}

Sensory neurons in the DRG are characterized by differences in mechanical, thermal and chemical responsiveness. Alterations in the response to mechanical and thermal stimuli in mice overexpressing GDNF and artemin demonstrate the potential of these growth factors to tune sensory neuron properties. In GDNF-overexpressing animals, mechanical thresholds of $\mathrm{C}$ fibre units innervating skin are decreased and a novel $\mathrm{C}$ fibre phenotype with low mechanical threshold and response to noxious heat is observed. The mRNA levels for the putative mechanosensitive ion channels ASIC2a and $2 \mathrm{~b}$ are increased, whereas transcript levels for the heat receptor TRPV1 are decreased. In artemin-overexpressing animals, heat thresholds in cutaneous $\mathrm{C}$ fibres are lowered, whereas mechanical thresholds are unaltered. TRPV1 transcript levels are increased in these animals but ASIC2 transcript levels are decreased. The observations demonstrate that different properties within a sensory neuron population can be regulated by different GFLs.

In ret mutant animals, TRPA1 expression is completely absent at postnatal day 14, although TRPV1 and TRPM8 appear unaffected. Despite analysis at other stages being pending, this observation indicates that ret signalling selectively regulates a specific afferent feature. In mice overexpressing GDNF or artemin, TRPA1 mRNA levels in DRG are increased indicating that different GFLs regulate TRPA1 expression.

\section{Perspectives}

Observations on a variety of gene products involved in specific neuronal functions hint at crucial regulatory processes that occur during the third week in mouse embryogenesis and that result in the development of sympathetic and sensory neuron classes differing in molecular equipment and, consequently, function. ret signalling is crucially involved in the expression of the cholinergic markers ChAT and VAChT at this time in sympathetic neurons. For TRPA1 expression in DRG neurons, the analysis of the effect of ret mutation at different developmental stages is required to show the stage of ret signalling involved in TRPA1 regulation. Comparison of the different GFL and GFRalpha mutant mice is necessary to specify the ligands active in vivo to induce cholinergic properties in sympathetic neurons and TRP expression in DRG neurons. Because of the prominent effect on neurite outgrowth, the alterations in neuron differentiation observed 
in mutant mice and in GFL-overexpressing mice may be secondary to altered neuritic growth and access to targetderived signalling molecules. In vitro studies on the respective neuron populations should demonstrate whether the GFLs identified in mutant analysis are capable of directly inducing transmitter properties or ion channels.

These considerations indicate the possible interaction of the different growth factor signalling pathways and the hierarchical organization of the different growth factor families or members within one family during neuronal differentiation. In sympathetic neurons, ret-dependent expression of cholinergic properties during late embryogenesis is followed by the gp130-dependent increase in the cholinergic neuron population at postnatal stages. However, whether ret signalling is still required postnatally in cholinergic sympathetic neurons is not clear. An analysis of whether such a succession of GFL and cytokine signalling is relevant for DRG neuron differentiation remains to be performed. In DRG neurons, a succession of neurotrophin and GFL signalling regulates the differentiation of nociceptor subpopulations. The acquisition of ret expression in trkA-positive neurons during late embryogenesis requires NGF, apart from its survival action, as shown in NGF/Bax double-mutant mice. The postnatal downregulation of trkA in these cells to form ret-positive trkA-negative non-peptidergic nociceptors in turn requires ret. Whether a comparable process operates during sympathetic neuron development seems unlikely since sympathetic neurons retain trkA expression into adulthood and widespread ganglionic ret expression precedes trkA initiation (U. Ernsberger, review in preparation). Thus, growth factor succession and interaction appears, at least in part, specific to sympathetic versus sensory lineages.

The mutual regulation of neurotrophin and GFL signalling pathways in the differentiation of non-peptidergic nociceptors marks an important step forwards in deciphering the hierarchical organization of regulatory pathways during the extrinsic control of neuronal differentiation (for a review, see Ibanez and Ernfors 2007). The finding that the transcription factor Runx1 is crucially involved in this process unfolds another essential issue. The proportion of trkA-positive DRG neurons increases more than two-fold in Runx1 mutant mice at the expense of ret-positive cells (Chen et al. 2006). This shows that a Runx transcription factor is part of the signalling pathways for regulating ret expression and in turn prompts the question regarding the intracellular transduction pathways mediating ret and GFL signalling.

\footnotetext{
Acknowledgements I thank Kathryn Albers (University of Pittsburgh, Pittsburgh, Pa., USA), Hermann Rohrer (Max Planck Institute for Brain Research, Frankfurt, Germany) and two reviewers for their critical reading and valuable comments on the manuscript. Klaus Unsicker is gratefully acknowledged for continuous support. Nicole Karch carried out the in situ hybridization for the presented figures. Ulla Hinz was extremely helpful in collecting the articles cited and Karin Bieber provided a wonderful place in which to read.
}

Open Access This article is distributed under the terms of the Creative Commons Attribution Noncommercial License which permits any noncommercial use, distribution, and reproduction in any medium, provided the original author(s) and source are credited.

\section{References}

Airaksinen MS, Saarma M (2002) The GDNF family: signalling, biological functions and therapeutic value. Nat Rev Neurosci 3:383-394

Albers KM, Woodbury CJ, Ritter AM, Davis BM, Koerber HR (2006) Glial cell-line-derived neurotrophic factor expression in skin alters the mechanical sensitivity of cutaneous nociceptors. J Neurosci 26:2981-2990

Amaya F, Shimosato G, Nagano M, Ueda M, Hashimoto S, Tanaka Y, Suzuki H, Tanaka M (2004) NGF and GDNF differentially regulate TRPV1 expression that contributes to development of inflammatory thermal hyperalgesia. Eur J Neurosci 20:2303-2310

Andres R, Forgie A, Wyatt S, Chen Q, Sauvage FJ de, Davies AM (2001) Multiple effects of artemin on sympathetic neurone generation, survival and growth. Development 128:3685-3695

Baudet C, Mikaels A, Westphal H, Johansen J, Johansen TE, Ernfors P (2000) Positive and negative interactions of GDNF, NTN and ART in developing sensory neuron subpopulations, and their collaboration with neurotrophins. Development 127:4335-4344

Bautista DM, Jordt SE, Nikai T, Tsuruda PR, Read AJ, Poblete J, Yamoah EN, Basbaum AI, Julius D (2006) TRPA1 mediates the inflammatory actions of environmental irritants and proalgesic agents. Cell 124:1269-1282

Bautista DM, Siemens J, Glazer JM, Tsuruda PR, Basbaum AI, Stucky CL, Jordt SE, Julius D (2007) The menthol receptor TRPM8 is the principal detector of environmental cold. Nature 448:204-208

Bennett DL, Koltzenburg M, Priestley JV, Shelton DL, McMahon SB (1998) Endogenous nerve growth factor regulates the sensitivity of nociceptors in the adult rat. Eur J Neurosci 10:1282-1291

Bennett DL, Boucher TJ, Armanini MP, Poulsen KT, Michael GJ, Priestley JV, Phillips HS, McMahon SB, Shelton DL (2000) The glial cell line-derived neurotrophic factor family receptor components are differentially regulated within sensory neurons after nerve injury. J Neurosci 20:427-437

Breeze NM, George AC, Pauers LE, Stucky CL (2005) Peripheral indlammation selectively increases TRPV1 function in IB4positive sensory neurons from adult mouse. Pain 115:37-49

Brodski C, Schaubmar A, Dechant G (2002) Opposing functions of GDNF and NGF in the development of cholinergic and noradrenergic sympathetic neurons. Mol Cell Neurosci 19:528-538

Bron R, Klesse LJ, Shah K, Parada LF, Winter J (2003) Activation of Ras is necessary and sufficient for upregulation of vanilloid receptor type 1 in sensory neurons by neurotrophic factors. Mol Cell Neurosci 22:118-132

Brown AG (1981) Organization of the spinal cord. Springer, Berlin Heidelberg New York

Burau K, Stenull I, Huber K, Misawa H, Berse B, Unsicker K, Ernsberger $\mathrm{U}$ (2004) c-ret regulates cholinergic properties in mouse sympathetic neurons: evidence from mutant mice. Eur J Neurosci 20:353-362

Burgess PR, Perl ER (1973) Cutaneous mechanoreceptors and nociceptors. In: Iggo A (ed) Handbook of sensory physiology, vol II. Somatosensory systems. Springer, Berlin Heidelberg New York, pp 29-78

Cacalano G, Farinas I, Wang LC, Hagler K, Forgie A, Moore M, Armanini M, Phillips H, Ryan AM, Reichardt LF, Hynes M, Davies A, Rosenthal A (1998) GFRalpha1 is an essential receptor component for GDNF in the developing nervous system and kidney. Neuron 21:53-62 
Caterina MJ, Schumacher MA, Tominaga M, Rosen TA, Levine JD, Julius D (1997) The capsaicin receptor: a heat-activated ion channel in the pain pathway. Nature 389:816-824

Caterina MJ, Leffler A, Malmberg AB, Martin WJ, Trafton J, PetersenZeitz KR, Koltzenburg M, Basbaum AI, Julius D (2000) Impaired nociception and pain sensation in mice lacking the capsaicin receptor. Science 288:306-313

Chen CL, Broom DC, Liu Y, de Nooij JC, Li Z, Cen C, Samad OA, Jessell TM, Woolf CJ, Ma Q (2006) Runx1 determines nociceptive sensory neuron phenotype and is required for thermal and neuropathic pain. Neuron 49:365-377

Colburn RW, Lubin ML, Stone DJ Jr, Wang Y, Lawrence D, D'Andrea MR, Brandt MR, Liu Y, Flores CM, Qin N (2007) Attenuated cold sensitivity in TRPM8 null mice. Neuron 54:379-386

Davis JB, Gray J, Gunthorpe MJ, Hatcher JP, Davey PT, Overend P, Harries MH, Latcham J, Clapham C, Atkinson K, Hughes SA, Rance K, Grau E, Harper AJ, Pugh PL, Rogers DC, Bingham S, Randall A, Sheardown SA (2000) Vanilloid receptor-1 is essential for inflammatory thermal hyperalgesia. Nature 405:183-187

Dhaka A, Murray AN, Mathur J, Earley TJ, Petrus MJ, Patapoutian A (2007) TRPM8 is required for cold sensation in mice. Neuron 54:371-378

Dhaka A, Earley TJ, Watson J, Patapoutian A (2008) Visualizing cold spots: TRPM8-expressing sensory neurons and their projections. J Neurosci 28:566-575

Durbec PL, Larsson-Blomberg LB, Schuchardt A, Costantini F, Pachnis V (1996) Common origin and developmental dependence on c-ret of subsets of enteric and sympathetic neuroblasts. Development 122:349-358

Elg S, Marmigere F, Mattsson JP, Ernfors P (2007) Cellular subtype distribution and developmental regulation of TRPC channel members in the mouse dorsal root ganglion. J Comp Neurol 503:35-46

Elitt CM, McIlwrath SL, Lawson JJ, Malin SA, Molliver DC, Cornuet PK, Koerber HR, Davis BM, Albers KM (2006) Artemin overexpression in skin enhances expression of TRPV1 and TRPA1 in cutaneous sensory neurons and leads to behavioral sensitivity to heat and cold. J Neurosci 26:8578-8587

Enomoto H, Araki T, Jackman A, Heuckeroth RO, Snider WD, Johnson EM Jr, Milbrandt J (1998) GFR alpha1-deficient mice have deficits in the enteric nervous system and kidneys. Neuron 21:317-324

Enomoto H, Crawford PA, Gorodinsky A, Heuckeroth RO, Johnson EM Jr, Milbrandt J (2001) RET signaling is essential for migration, axonal growth and axon guidance of developing sympathetic neurons. Development 128:3963-3974

Ernsberger U (2000) Evidence for an evolutionary conserved role of bone morphogenetic protein growth factors and phox2 transcription factors during noradrenergic differentiation of sympathetic neurons. Induction of a putative synexpression group of neurotransmittersynthesizing enzymes. Eur J Biochem 267:6976-6981

Ernsberger U (2001) The development of postganglionic sympathetic neurons: coordinating neuronal differentiation and diversification. Auton Neurosci 94:1-13

Ernsberger U (2004) Gene expression from precursor to mature neuron. In: Davies W, Morris B (eds) Molecular biology of the neuron, 2nd edn. Oxford University Press, Oxford, pp 29-73

Ernsberger U, Rohrer H (1996) The development of the noradrenergic transmitter phenotype in postganglionic sympathetic neurons. Neurochem Res 21:823-829

Ernsberger U, Rohrer H (1999) Development of the cholinergic neurotransmitter phenotype in postganglionic sympathetic neurons. Cell Tissue Res 297:339-361

Ernsberger U, Patzke H, Rohrer H (1997) The developmental expression of choline acetyltransferase (ChAT) and the neuropeptide VIP in chick sympathetic neurons: evidence for different regulatory events in cholinergic differentiation. Mech Dev 68:115-126
Ernsberger U, Reissmann E, Mason I, Rohrer H (2000) The expression of dopamine $\beta$-hydroxylase, tyrosine hydroxylase, and Phox2 transcription factors in sympathetic neurons: evidence for common regulation during noradrenergic induction and diverging regulation later in development. Mech Dev 92:169-177

Fang X, Djouhri L, McMullan S, Berry C, Waxman SG, Okuse K, Lawson SN (2006) Intense isolectin-B4 binding in rat dorsal root ganglion neurons distinguishes $\mathrm{C}$-fiber nociceptors with broad action potentials and high Nav1.9 expression. J Neurosci 26:7281-7292

Fjell J, Cummins TR, Dib-Hajj SD, Fried K, Black JA, Waxman SG (1999) Differential role of GDNF and NGF in the maintenance of two TTX-resistant sodium channels in adult DRG neurons. Brain Res Mol Brain Res 67:267-282

Funakoshi K, Nakano M, Atobe Y, Goris RC, Kadota T, Yazama F (2006) Differential development of TRPV1-expressing sensory nerves in peripheral organs. Cell Tissue Res 323:27-41

Goridis C, Rohrer H (2002) Specification of catecholaminergic and serotonergic neurons. Nat Rev Neurosci 3:531-541

Granholm AC, Srivastava N, Mott JL, Henry S, Henry M, Westphal H, Pichel JG, Shen L, Hoffer BJ (1997) Morphological alterations in the peripheral and central nervous systems of mice lacking glial cell line-derived neurotrophic factor (GDNF): immunohistochemical studies. J Neurosci 17:1168-1178

Guo A, Simone DA, Stone LS, Fairbanks CA, Wang J, Elde R (2001) Developmental shift of vanilloid receptor 1 (VR1) terminals into deeper regions of the superficial dorsal horn: correlation with a shift from TrkA to Ret expression by dorsal root ganglion neurons. Eur $\mathrm{J}$ Neurosci 14:293-304

Heuckeroth RO, Enomoto H, Grider JR, Golden JP, Hanke JA, Jackman A, Molliver DC, Bardgett ME, Snider WD, Johnson EM Jr, Milbrandt J (1999) Gene targeting reveals a critical role for neurturin in the development and maintenance of enteric, sensory, and parasympathetic neurons. Neuron 22:253-263

Hiltunen PH, Airaksinen MS (2004) Sympathetic cholinergic target innervation requires GDNF family receptor GFR alpha 2. Mol Cell Neurosci 26:450-457

Hiltunen JO, Laurikainen A, Airaksinen MS, Saarma M (2000) GDNF family receptors in the embryonic and postnatal rat heart and reduced cholinergic innervation in mice hearts lacking ret or GFRalpha2. Dev Dyn 219:28-39

Hjerling-Leffler J, Alqatari M, Ernfors P, Koltzenburg M (2007) Emergence of functional sensory subtypes as defined by transient receptor potential channel expression. J Neurosci 27:2435-2443

Honma Y, Araki T, Gianino S, Bruce A, Heuckeroth R, Johnson E, Milbrandt J (2002) Artemin is a vascular-derived neurotropic factor for developing sympathetic neurons. Neuron 35:267-282

Huber K, Ernsberger U (2006) Cholinergic differentiation occurs early in mouse sympathetic neurons and requires Phox2b. Gene Expr 13:133-139

Ibanez CF, Ernfors P (2007) Hierarchical control of sensory neuron development by neurotrophic factors. Neuron 54:673-675

Jänig W, McLachlan EM (1992) Characteristics of function-specific pathways in the sympathetic nervous system. Trends Neurosci $15: 475-481$

Jordt SE, McKemy DD, Julius D (2003) Lessons from pepper and peppermint: the molecular logic of thermosensation. Curr Opin Neurobiol 13:487-492

Josephson A, Widenfalk J, Trifunovski A, Widmer HR, Olson L, Spenger C (2001) GDNF and NGF family members and receptors in human fetal and adult spinal cord and dorsal root ganglia. J Comp Neurol 440:204-217

Kashiba H, Hyon B, Senba E (1998) Glial cell line-derived neurotrophic factor and nerve growth factor receptor mRNAs are expressed in distinct subgroups of dorsal root ganglion neurons and are differentially regulated by peripheral axotomy in the rat. Neurosci Lett 252:107-110 
Kashiba H, Uchida Y, Senba E (2001) Difference in binding by isolectin $\mathrm{B} 4$ to trkA and c-ret mRNA-expressing neurons in rat sensory ganglia. Brain Res Mol Brain Res 95:18-26

Kashiba H, Uchida Y, Senba E (2003) Distribution and colocalization of NGF and GDNF family ligand receptor mRNAs in dorsal root and nodose ganglion neurons of adult rats. Brain Res Mol Brain Res 110:52-62

Kobayashi K, Fukuoka T, Obata K, Yamanaka H, Dai Y, Tokunaga A, Noguchi K (2005) Distinct expression of TRPM8, TRPA1, and TRPV1 mRNAs in rat primary afferent neurons with adelta/c-fibers and colocalization with trk receptors. J Comp Neurol 493:596-606

Koltzenburg M (2004) The role of TRP channels in sensory neurons. Novartis Found Symp 260:206-213

Kramer I, Sigrist M, Nooij JC de, Taniuchi I, Jessell TM, Arber S (2006) A role for Runx transcription factor signaling in dorsal root ganglion sensory neuron diversification. Neuron 49:379-393

Kwan KY, Allchorne AJ, Vollrath MA, Christensen AP, Zhang DS, Woolf CJ, Corey DP (2006) TRPAl contributes to cold, mechanical, and chemical nociception but is not essential for hair-cell transduction. Neuron 50:277-289

Lähteenmaki M, Kupari J, Airaksinen MS (2007) Increased apoptosis of parasympathetic but not enteric neurons in mice lacking GFRalpha2. Dev Biol 305:325-332

LeDouarin NM, Kalcheim C (1999) The neural crest, 2nd edn. Cambridge University Press, Cambridge

Leitner ML, Molliver DC, Osborne PA, Vejsada R, Golden JP, Lampe PA, Kato AC, Milbrandt J, Johnson EM (1999) Analysis of the retrograde transport of glial cell line-derived neurotrophic factor (GDNF), neurturin and persephin suggests that in vivo signaling for the GDNF family is GFRa coreceptor-specific. J Neurosci 19:9322-9331

Lindfors PH, Voikar V, Rossi J, Airaksinen MS (2006) Deficient nonpeptidergic epidermis innervation and reduced inflammatory pain in glial cell line-derived neurotrophic factor family receptor alpha2 knock-out mice. J Neurosci 26:1953-1960

Lumpkin EA, Caterina MJ (2007) Mechanisms of sensory transduction in the skin. Nature 445:858-865

Luo W, Wickramasinghe SR, Savitt JM, Griffin JW, Dawson TM, Ginty DD (2007) A hierarchical NGF signaling cascade controls Ret-dependent and Ret-independent events during development of nonpeptidergic DRG neurons. Neuron 54:739-754

Luukko K, Suvanto P, Saarma M, Thesleff I (1997) Expression of GDNF and its receptors in developing tooth is developmentally regulated and suggests multiple roles in innervation and organogenesis. Dev Dyn 210:463-471

Malin SA, Molliver DC, Koerber HR, Cornuet P, Frye R, Albers KM, Davis BM (2006) Glial cell line-derived neurotrophic factor family members sensitize nociceptors in vitro and produce thermal hyperalgesia in vivo. J Neurosci 26:8588-8599

Michael GJ, Priestley JV (1999) Differential expression of the mRNA for the vanilloid receptor subtype 1 in cells of the adult rat dorsal root and nodose ganglia and its downregulation by axotomy. J Neurosci 19:1844-1854

Molliver DC, Wright DE, Leitner ML, Parsadanian AS, Doster K, Wen D, Yan Q, Snider WD (1997) IB4-binding DRG neurons switch from NGF to GDNF dependence in early postnatal life. Neuron 19:849-861

Moore MW, Klein RD, Farinas I, Sauer H, Armanini M, Phillips H, Reichardt LF, Ryan AM, Carver-Moore K, Rosenthal A (1996) Renal and neuronal abnormalities in mice lacking GDNF. Nature 382:76-79

Nishino J, Mochida K, Ohfuji Y, Shimazaki T, Meno C, Ohishi S, Matsuda Y, Fujii H, Saijoh Y, Hamada H (1999) GFR alpha3, a component of the artemin receptor, is required for migration and survival of the superior cervical ganglion. Neuron 23:725-736

Ogun-Muyiwa P, Helliwell R, McIntyre P, Winter J (1999) Glial cell line derived neurotrophic factor (GDNF) regulates VR1 and substance $P$ in cultured sensory neurons. Neuroreport 10:2107-2111
Okazawa M, Inoue W, Hori A, Hosokawa H, Matsumura K, Kobayashi S (2004) Noxious heat receptors present in cold sensory cells in rats. Neurosci Lett 359:33-36

Orozco OE, Walus L, Sah DW, Pepinsky RB, Sanicola M (2001) GFRalpha3 is expressed predominantly in nociceptive sensory neurons. Eur J Neurosci 13:2177-2182

Pattyn A, Morin X, Cremer H, Goridis C, Brunet JF (1999) The homeobox gene Phox $2 b$ is essential for the development of autonomic neural crest derivatives. Nature 399:366-370

Peier AM, Moqrich A, Hergarden AC, Reeve AJ, Andersson DA, Story GM, Earley TJ, Dragoni I, McIntyre P, Bevan S, Patapoutian A (2002) A TRP channel that senses cold stimuli and menthol. Cell 108:705-715

Price TJ, Flores CM (2007) Critical evaluation of the colocalization between calcitonin gene-related peptide, substance P, transient receptor potential vanilloid subfamily type 1 immunoreactivities, and isolectin B4 binding in primary afferent neurons of the rat and mouse. J Pain 8:263-272

Rossi J, Luukko K, Poteryaev D, Laurikainen A, Sun YF, Laakso T, Eerikainen S, Tuominen R, Lakso M, Rauvala H, Arumae U, Pasternack M, Saarma M, Airaksinen MS (1999) Retarded growth and deficits in the enteric and parasympathetic nervous system in mice lacking GFR alpha2, a functional neurturin receptor. Neuron 22:243-252

Schuchardt A, D'Agati V, Larsson-Blomberg L, Costantini F, Pachnis V (1994) Defects in the kidney and enteric nervous system of mice lacking the tyrosine kinase receptor Ret. Nature 367:380-383

Schultzberg M (1983) The peripheral nervous system. In: Emson PC (ed) Chemical neuroanatomy. Raven, New York, pp 1-51

Silverman JD, Kruger L (1990) Selective neuronal glycoconjugate expression in sensory and autonomic ganglia: relation of lectin reactivity to peptide and enzyme markers. J Neurocytol 19:789-801

Skoff AM, Adler JE (2006) Nerve growth factor regulates substance P in adult sensory neurons through both TrkA and p75 receptors. Exp Neurol 197:430-436

Snider WD (1994) Functions of the neurotrophins during nervous system development: what the knockouts are teaching us. Cell 77:627-638

Stanke M, Duong CV, Pape M, Geissen M, Burbach G, Deller T, Gascan H, Otto C, Parlato R, Schutz G, Rohrer H (2006) Targetdependent specification of the neurotransmitter phenotype: cholinergic differentiation of sympathetic neurons is mediated in vivo by gp 130 signaling. Development 133:141-150

Stucky CL, Lewin GR (1999) Isolectin B(4)-positive and -negative nociceptors are functionally distinct. J Neurosci 19:64976505

Stucky CL, Rossi J, Airaksinen MS, Lewin GR (2002) GFR alpha2/ neurturin signalling regulates noxious heat transduction in isolectin B4-binding mouse sensory neurons. J Physiol 545:43-50

Tamura S, Morikawa Y, Senba E (2005) TRPV2, a capsaicin receptor homologue, is expressed predominantly in the neurotrophin-3dependent subpopulation of primary sensory neurons. Neuroscience 130:223-228

Tominaga M, Caterina MJ, Malmberg AB, Rosen TA, Gilbert H, Skinner K, Raumann BE, Basbaum AI, Julius D (1998) The cloned capsaicin receptor integrates multiple pain-producing stimuli. Neuron 21:531-543

Woodbury CJ, Zwick M, Wang S, Lawson JJ, Caterina MJ, Koltzenburg M, Albers KM, Koerber HR, Davis BM (2004) Nociceptors lacking TRPV1 and TRPV2 have normal heat responses. J Neurosci 24:6410-6415

Zwick M, Davis BM, Woodbury CJ, Burkett JN, Koerber HR, Simpson JF, Albers KM (2002) Glial cell line-derived neurotrophic factor is a survival factor for isolectin B4-positive, but not vanilloid receptor 1positive, neurons in the mouse. J Neurosci 22:4057-4065 